\title{
Strategies That Work When Property Rights Don't
}

\author{
Bharat Anand \\ Harvard Business School (*)
}

\author{
Alexander Galetovic \\ Universidad de Chile (**)
}

\begin{abstract}
In many sectors property rights over knowledge and information are weak as they are embodied in employees, competitors can copy or customers can pirate. Yet comprehensive studies show that firms systematically invest in these assets. We offer a simple taxonomy of strategies that firms use to cope with weak property rights.
\end{abstract}

We classify these strategies in three groups: (i) Some firms threaten offenders with strong competition. (ii) Other firms exploit complementarities and offer potential offenders a better deal than they can get elsewhere. (iii) And yet other firms exploit weak property rights and make profits on complementary assets or products that they can own.

We go beyond taxonomy by showing when a particular strategy works. It depends systematically on the characteristics of both the asset and the investing firm.

Key words: complementarities, firm scope, holdup, piracy, weak property rights

JEL Classification: L23, O31, O32, O34

(*) Soldiers Field Road, Boston, MA02163. banand@ @bs.edu. Anand gratefully acknowledges the financial support of the Division of Research at Harvard Business School.

(**) Center of Applied Economics (CEA), Universidad de Chile, Av. República 701, Santiago, Chile. agaleto@ dii.uchile.cl. Galetovic gratefully acknowledges the financial support of the Hewlett Foundation under an institutional grant to CEA. 


\section{Introduction}

In 1999, the music industry was first "Napsterized." Thanks to the proliferation of peerto-peer file-sharing protocols, consumers began to freely copy and distribute digitized files of songs on a massive scale. As a result, in fiscal year 2002, the major recording studios saw their sales drop by almost ten percent. To combat piracy, the studios attempted to take copyright offenders to court and looked for increasingly sophisticated technologies that might make it difficult to pirate digitized content. But the legal and technological approaches had limited success, and the industry increasingly searched for "new business models" that might allow them to capture the value created by their investments into the financing and marketing of music. For several years, however, firms remained mystified about where such business models would come from, what form they might take, and what logic should underpin the strategic response to piracy. Indeed, in May 2002, Disney CEO Michael Eisner declared: “[T]he only thing I can say is it's very hard to create a business model against something that is a perfect copy for free. It would even challenge the greatest business man that ever was."2

As it turns out, the music industry is not alone in its dilemma. Indeed, firms in many industries are finding it increasingly difficult to establish property rights over the informationintensive assets that they invest in? knowledge, information, ideas, and human capital? or the products that they develop. Nevertheless, they continue to invest in assets or products that they cannot own. So, how is it that these firms can cope with the challenge of insecure ownership rights over these assets? And, how can they recoup their investments in these assets?

We examine the strategies that firms use to capture value from such assets, and offer a simple taxonomy that can assist managers in tackling similar problems in different settings. Implicit in this approach is the claim that the problem facing the music industry (and, increasingly, the movie studios) is not unique. Imposing some structure on the problem and identifying common solutions may also assist firms in their search for an effective solution rather than relying purely on an Archimedean stroke of genius. Understanding how firms in other industries resolve similar dilemmas may not, of course, yield the magical solution for the

\footnotetext{
1 See "Copy Cat Culture", Business and Finance (2002):33, Ham and Atkinson (2000), and Langenderfer and Cook (2001).

2 "This is War: Should The Computer Industry Protect Hollywood from Digital Theft?" Fortune, 145 (11), 27 May 2002.
} 
recording industry. But, as we show later, it can be used to shed light both on the limits and promise of different classes of strategies, and on why it is that some firms have responded differently than others when facing a similar dilemma.

As we describe below, the strategies that firms use are both rich and varied, and can work by relying on market incentives rather than legal ones. In some cases, market-based strategies work by successfully minimizing the threat of third-party appropriation; in other cases, they work by exploiting the incentive of others to appropriate value. In some cases, firms adapt their internal organization and governance of projects in ways that allow them to cope with weak property rights. In other cases, firms alter their organizational boundaries and use their ownership of complementary assets to capture value created by assets they cannot own. Or, the resulting market structure may endogenously adapt to grant firms enough market power to capture value. But we go beyond taxonomy in this paper by showing that whether or not a particular strategy works depends systematically on the characteristics of both the asset and the financier.

In Section II, we study a simple model that examines how firms can capture value by investing in ideas despite weak property rights. We use the model's central results to extract four basic principles that organize the taxonomy, in Section III, of how firms tackle similar problems in a variety of settings. Section IV applies these principles to examine how firms in the music industry might confront piracy. Section V concludes with some decision traps that managers should avoid when investing in assets that the firm cannot own.

\section{The Financing of Ideas}

Property rights over "ideas" are virtually impossible to establish. Consequently, the financing of projects in which the key input is an "idea" has long been considered a problem for financiers and, by implication, entrepreneurs looking for finance. Hart and Moore (1994) examined the difficulties in structuring financing arrangements for "an entrepreneur who needs to raise funds . . but cannot commit not to withdraw his human capital from the project." But this threat of repudiation or holdup is not specific to small entrepreneurial ventures alone. Indeed, many large, established companies have found it difficult to prevent employees from leaving and commercializing ideas. Perhaps the most cited example of a firm that consistently failed to capture value from the ideas it financed is Xerox and its research arm, Xerox PARC. As The Economist noted, "Xerox PARC is famous for having pioneered ideas (including a superior 
personal computer, the facsimile machine, the Ethernet, and the laser printer) that made fortunes for many of its Silicon Valley neighbours but little for itself." Elsewhere, "people at Bell Labs have still not forgotten how, half a century ago, William Shockley took the transistor idea, which he and his colleagues had invented at Murray Hill, to Palo Alto in California and started a company (Fairchild Semiconductor) that eventually became Intel." Indeed, the notion that ideas walk with individuals rather than residing in the black box of firms was strikingly illustrated in a survey of 100 founders of the 1989 Inc 500 fastest-growing private companies in the United States. Bhide (1994) found that 71 percent of these founders "replicated or modified an idea encountered through previous employment."

In Anand and Galetovic (2000a), we studied the financing of ideas when property rights are weak. The premises of the model are that ideas are embodied in individuals (we call them "researchers") and that it is difficult to establish property rights over these ideas. The reason is that the asset in question (the idea) cannot be well defined in advance, and the embodied asset (the researcher's human capital) cannot be owned. Weak property rights make ex-post hold-up by the researcher possible because, after receiving financing, the researcher may walk away from the firm to develop the idea elsewhere. Financiers are aware ex ante, and so the question is why would they ever finance in the first place. As we will show, different financiers are differently endowed to deal with weak property rights. These endowments determine whether they can deal with weak property rights and, if they can, how.

The simple model described in the next section is unlikely to capture all the particular features of varied settings. For example, the challenge of insecure property rights faced by the recording industry primarily stems not from the difficulty in establishing secure contractual relations with human capital (artistes) but from the difficulty in preventing consumers from easily copying and disseminating the final product. But, as we show later, the lessons extracted from this simple model still extend to many of these other settings.

\section{II (a). A Simple Model ${ }^{3}$}

The basic structure. Consider a model with only two periods: a research phase and a development phase; and three dates: date 0 , before research; date 1, in-between research and development; and

3 The rest of this section draws on Anand and Galetovic (2000a). 
date 2, after development (figure 1 shows the time line of the game). The output of the research phase is an idea. This idea is necessary to develop a marketable innovation whose value is $S$. To obtain the idea it is necessary to invest $R$. The development cost is $D^{r}$ if the researcher partners with the venture capitalist (VC) (call this "independent development") and $D^{c}$ if the researcher partners with the corporation (call this "joint development").

In both the research and the development phases, the researcher can obtain funding from either a VC or a corporation, and it can switch financiers at date 1. Switching in-between research and development opens the door to hold-up? the idea becomes embodied in the researcher, who can leave to develop it elsewhere. We model the strength of property rights as follows. If the researcher switches at date 1 , after the research phase, to pursue development elsewhere, the financier can establish its rights over the innovation's cash flow as specified in the contract signed at date 0 with probability $v$; with probability 1 ? $v$, the financier is unable to establish its rights. Thus, if $v$ is close to 1 , then property rights are "strong"; if $v$ is small, then property rights are "weak."

Complementarities, account opaqueness and spillovers. Corporations and VCs are different in fundamental ways. Of course, these differences do not stem from the capital that each provides, but from the way they organize the projects they finance. Specifically, a corporation encompasses multiple projects that are joint or non-separable, whereas VCs finance projects that are legally and functionally separate.

Jointness or non-separability of activities may lead to "synergies" or complementarities across projects that the corporation can exploit when projects are more closely integrated. Examples include shared lab facilities, common purchasing facilities, and a brand name. We will see that, from the perspective of the holdup problem wrought by weak property rights, this is important because corporations may have more resources with which to cope and bribe the researcher to stay. We can model situations in which corporations can exploit complementarities assuming that $D^{c} ? D^{r}$.

But in other situations, jointness may be a curse rather than a boon. Integration typically dilutes incentives by decreasing the autonomy of managers, which implies that stand-alone 
financing may give stronger incentives. ${ }^{4}$ Similarly, joint activities make proper accounting of the costs and revenues specific to a given project more difficult. ${ }^{5}$ Account opaqueness limits the ability of the corporation to share surplus with the researcher. We can model situations in which jointness imposes net costs by assuming that $D^{c} ? D^{r}$.

There is a third implication of jointness: it may lead to internal spillovers from the researcher to the corporation so that part of the knowledge accumulated by the researcher may leak to the corporation. If the researcher leaves, spillovers give rise to a form of "reverse holdup," as the corporation can threaten to compete with the researcher. ${ }^{6} \mathrm{We}$ model internal spillovers as follows. If the researcher leaves the corporation, she is able to develop the innovation with probability $b$. In that case, the corporation earns surplus $S^{c}$ and the researcher surplus $S^{r}$, with $S^{c} ? S^{r}$ ? $S$. By contrast, the VC cannot exploit local spillovers.

Thus, we have determined that financiers differ in three relevant dimensions: complementarities or diseconomies of scope; ability to commit to share surplus; and spillovers. We now show that these characteristics interact with the strength of property rights and determine: (a) whether a corporation, a VC or neither is the most appropriate source of finance; and (b) what strategy the financier should follow to cope with weak property rights.

\section{II (b) Key Results}

Figure 1 below presents the key results. The $x$-axis denotes the strength of property rights, $v$, over the idea, which ranges from 0 (weak property rights) to 1 (strong property rights). The vertical axis denotes the magnitude of complementarities (the positive quadrant) or diseconomies of scope (the negative quadrant) within the corporation. Within regions I and II, where property rights are strong, the $\mathrm{VC}$ always finances research. When property rights are weak, by contrast, all depends on complementarities and spillovers. When these are significant,

\footnotetext{
${ }^{4}$ In Anand et al. (2003), we endogenize the extent to which projects within a corporation are kept separate or are integrated, and show that it will be optimal not to provide complete autonomy to project managers.

5 This may be due to several factors: (a) isolating the components of cost of the sources of revenue is simply a harder task when projects are integrated; (b) the corporation may have an incentive to misrepresent costs and revenues so as to decrease payouts to the researcher. Holmstrom (1989), for example, argues that either "the best intentioned firm does not know capital costs," or, even if it does, it "has control of many levers to make accounting measures less reliable."

6 See Anton and Yao (1994).
} 
the corporation is willing to finance research (regions V and VI). Similarly, when diseconomies of scope are strong (region III), the VC is willing to finance. But in region IV, where both financiers are alike, competition and weak property rights kill financing. We discuss each case in turn.

Strong property rights First consider regions I and II, where $v ? R / S$. Then the VC always finances research, because

$$
v S ? R
$$

that is, when property rights are sufficiently strong, the financier can recoup its costs in expected value. How strong is "strong enough" depends on the characteristics of the project being financed. To see why, note that the financier can never be sure of getting back any surplus if $v$ ? 1 . Instead, the maximum payment it can expect to receive is $v S$, which is sufficient to induce ex-ante finance as long as it exceeds the upfront financing cost $R$, that is $v S ? R$. This implies that as $v$ falls and the strength of property rights declines, the tendency to finance projects that generate large surpluses $S$ ? i.e., the "sure hits"? increases.

Figure 1: The financing of ideas

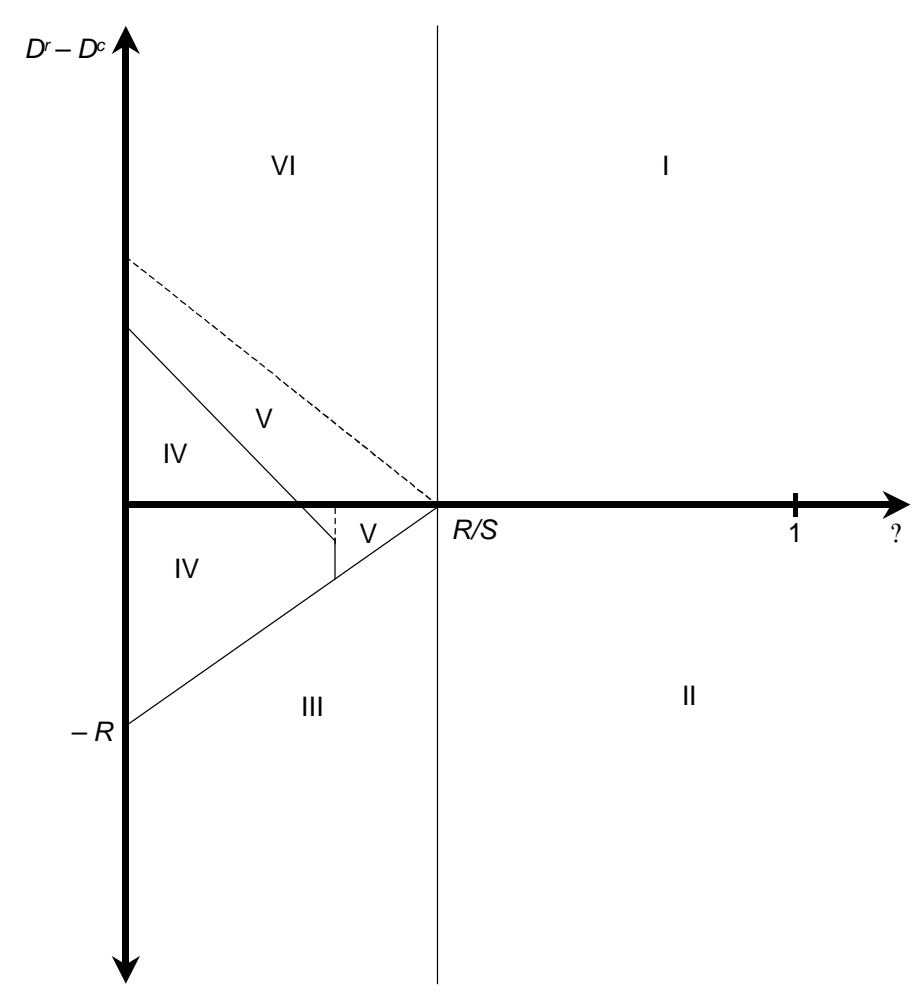


We may note that in regions I and II, corporate financing of ideas is never observed in equilibrium. This may seem strange. Surely corporations are willing to finance an idea that they can own! But it turns out that with strong property rights the researcher prefers independent financing by the VC. Why? Recall that the corporation cannot commit to share any surplus with the researcher at the time of financing. This implies that the researcher's bargaining power stems only from her outside option of possible breakaway. Precisely because property rights are strong, this outside option would be of little value to the corporation. By contrast, the independent financier can commit ex-ante to share surplus with the researcher and, thus, is the preferred financing alternative.

Note that these results suggest that the apparent dominance of $\mathrm{VC}$ financing of research does not stem from any intrinsic advantage to venture capital finance. Nor does it depend on any superior ability of VCs to search, screen, or identify promising projects. Rather, it derives from the fact that any attempt by corporations to more closely integrate projects to extract complementarities also has a dark side? namely, the increased incentive to manipulate accounts and reduce surplus sharing with employees or managers. Numerous examples of conflicts between corporations and employees (or suppliers more generally) can be traced to this characteristic.

For example, consider the following account of a lawsuit against News Corporation and Fox Television Network by David Duchovny, the star of one of the most popular programs on the network, X-Files:

Duchovny's suit ... accuses Fox of limiting the potential back-end gross of the show? and thereby his take through profit participation points? by cutting sweetheart deals with Fox-owned entities at below-market prices. ${ }^{7}$

Profit participation in Hollywood has always been a messy business. Showbiz lawyers have long charged that studios often resort to creative accounting practices and downright fraud to hide the true grosses of hit movies and TV shows. But the suspicion has never been greater on the part of many artists than in the new era of vertical integration: "Intra-company transactions

\footnotetext{
7 "Synergize This," by Cynthia Littleton, Variety, August 23-29, 1999, page 27.
} 


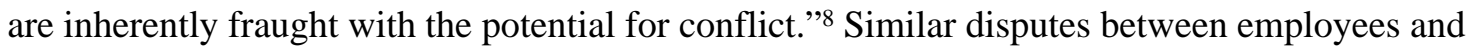
firms over account manipulations and surplus sharing have contributed to strikes in professional sports. For example, foreshadowing the lockout in professional basketball in 1999, owners claimed that "we need to slow the growth" in salaries for high-end players, whereas players pointed out that "[O]wners never have volunteered to open their books and let the bottom lines for all 29 teams be made a public record." 9

It is important to note that strong property rights stimulate efficient switching to corporate financing after research. As we show in Anand and Galetovic (2000a, Proposition 3.1), in region I it pays both the researcher and the $\mathrm{VC}$ to allow a breakaway to the corporation to take advantage of complementarities after the idea has been developed. Essentially, the VC is willing to allow efficient breakaway because strong property rights allow her to capture complementarities realized by the corporation through an appropriate breakaway fee. Because property rights are strong, the VC is willing to finance, anticipating that the researcher will switch to the corporation in the development stage. Of course, in region II, the $\mathrm{VC}$ also finances the development stage? it would be inefficient to switch to a corporation and suffer diseconomies of scope.

Weak property rights and the importance of complementarities. We now turn to weak property rights, that is $v S ? R$. First note that, even though the corporation and the VC compete after research, the project may be able to get financing. But for this to occur, one financier must offer a sufficiently large cost advantage in development. To see this, assume that complementarities are strong and that the corporation has a large cost advantage in development (i.e. $D^{r}$ ? $D^{c}$ ? 0 and large). Then, if the researcher gets first-stage financing from a corporation, the corporation will be able to prevent holdup if the surplus from the project, $S-R-D^{c}$, exceeds the researcher's outside option in the second stage, $(1-v) S-D^{r}$. The reason is that the corporation's competitive advantage creates a surplus large enough to entice the researcher to stay. Intuitively, weak property rights improve the researcher's outside option and make projects more expensive to finance. Complementarities create a surplus that the corporation can use to sweeten the

\footnotetext{
8 A few months later, producer Steven Bochko also filed a lawsuit against Fox for selling the show NYPD Blue (in which Bochko had a profit participation stake) to its own cable channel, FX, at below-market prices, and argued that " [...] this is just the 1999 version of what they used to call "creative bookkeeping." In "Media Mergers Bottom Line So Far? Lawsuits," by Brian Lowry, Los Angeles Times, Sept. 17, 1999.

9 "NBA Lockout Appears Certain," by Eddie Sefko, Houston Chronicle, June 28, 1998.
} 
researcher's deal and make him stay? carrots to prevent holdup. Mutatis mutandis, exactly the same argument explains when a VC may be willing to finance with weak property rights.

But why might financiers have any advantage over others? It's not deeper pockets, but differences in the nature of related assets that financiers typically can offer. In the case of a corporate financier (region VI), a researcher may be able to leverage existing operations to offer superior access to customers, channels, or supplies. It is not surprising, for example, that Kids R Us was founded by Toys R Us so as to leverage the latter's industry-specific skills to select styles and manufacturers, buy, display, and sell products, process information, control inventories, and even benefit from a related brand name.

Conversely, if access to relationships and knowledge, rather than operations and physical assets, are key, then independent financiers may have advantages (region III). For example, Fortune magazine noted that some venture capitalists offer a combination of broad-based expertise from being successful entrepreneurs themselves and a unique network of personal relationships, and that "Kleiner Perkins' pals . . . include the founders of Netscape, Cisco, AOL, Intuit, Intel, TCI, Sun, Lotus, and Comcast.”

Region V: when internal spillovers help financing. Can financing ever occur when property rights are weak and no type of financier has an appreciable cost advantage in development? The model suggests a third avenue by which the corporation can mitigate the threat of holdup? the ability to exploit the internal spillovers of research. When spillovers are sufficiently large, a corporation may be able to compete with the researcher that it financed, even after he leaves.

To see the effect, recall that the corporation will be able to compete in the product market with probability $b$, so that the expected surplus to the researcher (gross of development costs) is $(1-v)\left[(1-b) S+b S^{r}\right)$ where $S^{r} ? S$ is the researcher's surplus when competing with the corporation. If this surplus does not cover the development cost $D^{r}$, no financier will be willing to finance independent development. In other words, some trivial algebra shows that holdup does not occur if 
$(1 ? v)^{?}\left(1 ? b^{*}\right) S^{\%} ? D^{r}$

where $b^{*} ? b$ ? $? S^{r} / S$ ?

As Figure 1 (region V) shows, local spillovers enlarge the area of corporation finance because the threat of product market competition reduces the value of the researcher's outside option and makes holdup less attractive. This helps him to get financing for research. In other words, ex post competition is used as a stick to prevent holdup. Notice that product market competition does not actually occur in equilibrium; the mere ability to do so is enough to forestall breakaway by the researcher. But the key point is that the threat of a "reverse holdup" by the corporation can neutralize the threat of holdup by the researcher.

Spillovers are often thought to prevent researchers from appropriating the value created by their ideas. Yet, this result suggests that spillovers can help researchers by enlarging the scope for financing them. The intuition is that both researchers and financiers confront problems of appropriability? one due to weak property rights, the other due to spillovers? which cancel out instead of adding up! More generally, the example suggests that strategies to overcome certain types of market imperfections may rely on creating other imperfections or frictions, an application of the well-known second-best principle.

\section{II (c). Five basic principles}

This simple model yields five basic principles for the broader analysis of strategies to tackle the challenge of weak property rights:

(1) The limits of the law. Legal remedies will not always work; nor are they always needed. Regions I and II, which correspond roughly to the case in which laws are "strong enough" to protect the financier, do not encompass the entire region of financing.

(2) The use of carrots to prevent holdup. Financiers need not have monopoly power to ensure that they can recover their costs. Indeed, regions V and VI suggest that market power per se is not sufficient; rather, market power in the relevant complementary asset is key to preventing holdup. The reason is that complementarities enable firms to increase the pie. Offering the researcher the carrot of sharing in this larger pie provides her with incentives not to leave. Below, 
we examine particular strategies in more detail to shed light on what these complementary assets might be in practice.

(3) The use of sticks to prevent holdup. Appropriability problems can cancel out rather than add up. As said before, this is a special case of a more general second-best principle in economics: when you add a second distortion, welfare may increase. In this case, internal spillovers undo the deleterious effects of the initial distortion? weak property rights. Region V suggests that this principle may be useful in devising strategies to cope with weak property rights over assets. Common examples include strategies that increase the threat of retaliation to the researcher or increase "reverse-holdup."

(4) Strategies that exploit weak property rights. Financiers may recoup their costs even if there is breakaway by the researcher in equilibrium (region I), and they may thus share in a larger surplus. Consequently, strategies need not be directed solely at preventing breakaway. Region I shows that financiers may recoup their research costs even if the researcher leaves after getting finance. Below, we build on this principle and examine a class of strategies that exploit, rather than mitigate, holdup.

(5) Diversity: what works for one does not necessarily work for another. A central lesson of the model is that diversity of strategies rules in the financing of ideas. But, as illustrated above, we can go beyond this observation, noting that whether or not a strategy works will depend systematically on the nature of the asset being financed? i.e., the strength of property rights over it? and the nature of the rest of the assets or activities in which the financier is involved.

In subsequent sections, we apply these simple principles to examine strategies that firms use in a variety of different markets to overcome the problem of weak property rights over assets.

\section{Strategies to Cope with Weak Property Rights}

The array of strategies discussed in the rest of the paper are summarized in Figure 2 below: 
Figure 2: Strategies to Capture Value in the presence of Insecure or Non-existent Property Rights

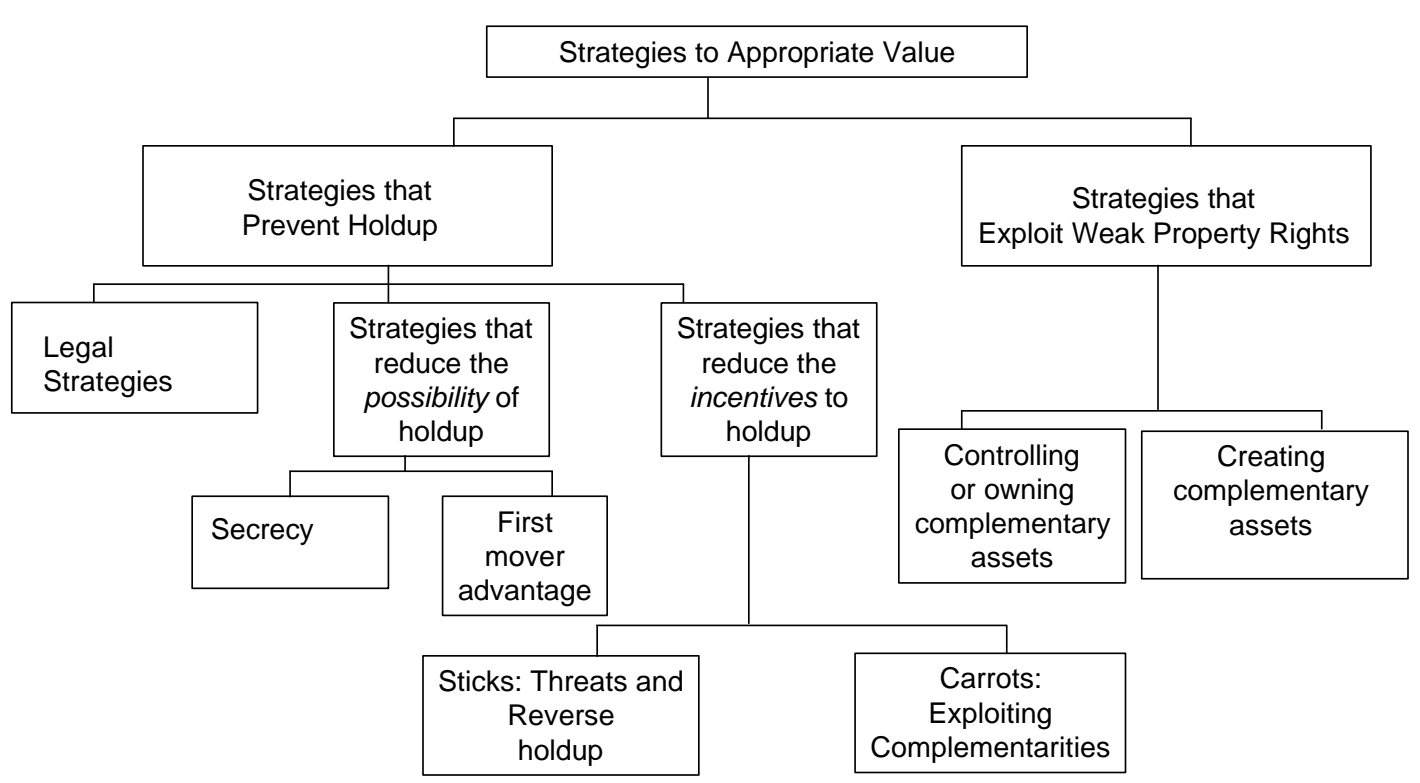

\section{III (a). Law and Disorder}

The first, and often last, line of defense that many firms have used to deal with weak property rights has been to call for either stronger laws or stronger enforcement of existing laws. The fact that property rights are being violated, so the argument goes, is merely evidence that existing laws must be allowing it. Toughening penalties for infringement or endowing rights holders with broader protection would, therefore, prevent such infringements from occurring.

While legal remedies have obvious merits and can be effective in many circumstances, in many others, they are not. The difficulty in relying on the law to secure, or the courts to enforce, property rights over certain types of assets or resources has been documented repeatedly. In his summary on "Property Rights," Armen Alchian noted in 1967 that

[t]he cost of establishing private property rights so that I could pay you a mutually agreeable price to pollute your air may be too expensive. Air, underground water, and electromagnetic radiation, for example, are expensive to monitor and control. Therefore, a person does not effectively have enforceable private property rights [over these assets]. The inability to cost-effectively 
monitor and police uses of your resources means "your" property rights over "your" land are not as extensive and strong as they are over some other resources, like furniture, shoes, or automobiles.

Similar issues prevent legal protection of many types of intangible assets. Consider patents, for example. Key questions that have been addressed in the intellectual property literature are the optimal length and breadth of patent protection (that is, for how long should an inventor receive statutory protection for her invention, and how broad should the coverage of the patent be), and, as a consequence, what should count as an infringement? But this question? and, consequently, the extent of protection offered de facto by the law? are often very hard to answer in practice. As Merges and Nelson (1990, p. 841) point out, "the legal principles and objective evidence often leave considerable room for discretion," both in decisions involving the scope of patents by the Patent Office and in the litigation that accompanies allegations of patent infringement. For example, should a patent be awarded for new uses of a previously patented product? Should an alleged infringement be treated as such on the grounds that it is equivalent to an earlier patent, even if not exactly identical? Indeed, a more fundamental question is whether or not it is even possible to precisely circumscribe the boundaries of patent coverage. ${ }^{10}$

The limits to legal remedies were most strikingly documented in a pair of surveys by economists at Yale (Levin et al, 1987) and Carnegie-Mellon (Cohen et al, 2000). Interviews with over 600 managers across 130 lines of business in 45 industries revealed that

[t]he picture is striking. For new processes, patents were generally rated the least effective of the mechanisms of appropriation. Generally, lead time, learning curves, and sales or service efforts were regarded as substantially more effective than patents in protecting products. (Moreover), in only one industry, drugs, were product patents regarded by a majority of respondents as strictly more effective than other means of appropriation (Levin et al, p. 794-796)

In other words, managers in most industries observed that existing patent laws were rather ineffective to protect their investments in $R \& D$. And these surveys concerned the effectiveness of patent law, not copyright or trade secret law! In these cases, or where firms attempt to recoup investments in assets that are as difficult to describe and define as "ideas" or

10 Anand and Khanna (2000) argue that because it is often difficult to clearly specify the boundaries and content of some intangible assets, it should also, a posteriori, be difficult to allocate property rights over these assets. 
"skills" or "relationships," many have argued that constraints to the law are significantly greater. ${ }^{11}$ O'Donoghue, et al. (1998) note similar findings from additional studies:

There is at least some evidence that effective patent lives are short. Mansfield (1984) reports from survey evidence that in some industries $60 \%$ of patents are effectively terminated within 4 years, which is considerably less than the statutory life of 17 years. . . . Further evidence of short effective patent lives comes from patent renewal data: Schankerman and Pakes (1986) conclude that European patents lose on the order of $20 \%$ of their value per year, and Pakes (1986) reports that only 7 percent of French patents and 11 percent of German patents are maintained until the patent expires [see also Pakes and Schankerman (1984)].

The story is similar in other industries. Bhattacharya and Nanda (2000) note that despite the profusion of new financial products in the last decade, "financial products cannot be patented and all details of a new security become publicly available once the offering is filed with the SEC." 12 And, in the context of recent piracy in the music industry, the difficulties in relying solely on legal protection to solve the problem of infringement has been elegantly noted in a recent article by Shirky (2001). He argued that "the music industry is losing not the right to enforce copyright but the ability to do so."

What does this imply for firms and their ability to recoup investments in assets over which property rights are weak? As Alchian (1967) argued,

[W] hen private property rights are unavailable or too costly to establish and enforce, substitute means of control are sought. Government authority, expressed by government agents, is one very common such means.

But there are other means. As Gallini and Scotchmer (2002) note, intellectual property is merely one of a variety of incentive schemes to promote $R \& D$, and other protections can substitute for a formal reward system. Indeed, managers often argue that limits to legal remedies make it necessary to consider strategies that encompass so-called "creative business models" or market-based solutions. However, in many cases, it is not clear what these market solutions might be and, more importantly, whether these solutions can be designed systematically. "Creative

11 For example, Anand and Khanna (2000) note that copyright attaches only to an expression of an idea, not the idea itself, making it considerably easier to invent around these rights. Furthermore, another important feature of copyright law, distinct from patent law, is that it is not held to be infringed if another firm independently creates the article in question. 
business models" are typically given no more than lip service. The rest of this paper aims to fill this gap by providing a systematic approach to market-based solutions that firms can use to cope with weak property rights.

\section{III (b). Market-Based Solutions: Secrecy and First-Mover Advantages}

Secrecy. It is often claimed that firms may rely on secrecy (Horstmann et al, 1985). In the previously cited Levin et al survey, for example, firms often claimed to rely on some form of secrecy to appropriate value from innovations. An additional attraction of trade secrets is that they achieve an indefinite period of exclusive use for the firm's invention or discovery. In practice, however, von Hippel (1988, p. 54) argues:

[Secrecy] is an option only for innovations that can in fact be kept secret: the holder of a trade secret cannot exclude anyone who independently discovers it or who legally acquires the secret by such means as accidental disclosure or reverse engineering. .... [T] rade secrets have proven to be effective only with regard to (1) product innovations that incorporate various technological barriers to analysis (e.g., the formula for Coca-Cola) or (2) process innovations that can be hidden from public view (e.g., process equipment kept behind factory walls).

Indeed, secrecy presumes that firms can choose not to disclose ideas to the market but still somehow extract rents from their commercialization. ${ }^{13}$ Another reason why secrecy might be of limited practical use is that it may be difficult, even impossible, to keep secrets from employees because these secrets typically reside with the individuals and are not 'in the firm.' As The Economist notes:

[T]he term 'technology transfer' is something of an oxymoron. Real innovations do not move from laboratory to shopfloor as patents, research reports, or even working prototypes. To stand any chance of success, they have to be transferred as concepts embedded in people's heads. ${ }^{14}$

Consequently, the ability to keep a secret either relies on a "black box" conception of firms or presumes that firms somehow have access to employee contracts that are strong enough

\footnotetext{
12 See also Lerner (2002).

13 But see recent analyses by Anton and Yao $(2002,2003)$ that study how a seller can appropriate value even under these circumstances e.g., through partial disclosure or the inclusion of certain protective clauses in contracts with potential buyers.

14 “Adopting Orphans," February 20, 1999.
} 
to establish property rights. This may work sometimes. But in many other cases it simply assumes away the problem caused by weak property rights.

A first-mover advantage. Exploiting a first-mover advantage in commercializing assets is another way for firms to appropriate value from assets over which property rights are weak. The logic is straightforward? being first to market allows a firm to capture monopolistic rents, albeit during short time windows, until reverse engineering, imitation, or piracy occurs. Palm and Netscape offer two examples. But companies like Intel have taken this a step farther and base their strategy in consistently being the "first to market."

\section{Case Study 1: Intel's Repeatable First-to-Market Strategy}

Innovations in Intel's core business? microprocessors? have been notoriously difficult to patent or protect via other legal mechanisms. Levin et al (1982, p. 80) noted that while certain innovations could be patented in semiconductors, "what appears impossible to patent is the actual physical layout of an integrated circuit of even moderate complexity. The principal reason for this is the difficulty of rendering a full verbal description of the circuit layout." Similarly, Casadesus-Masanell and Yoffie (2002) note that technology moves so rapidly that patents quickly become economically obsolete. Also, because most companies draw from common underlying technology bases, it is not always clear who might be infringing upon whom. To compound these problems, for a typical cohort of chips, prices fall by almost 30 percent within a few months of introduction and by up to 75 percent within two years. In spite of these difficulties, Intel's cumulative profits between 1987 and 1997 exceeded $\$ 20$ billion, making it one of the most profitable firms in the world.

So, how did Intel sustain its first-mover advantage across product generations? It followed a multi-pronged approach: first, it made massive investments in product design and manufacturing and process technologies to ensure that it launched new products ahead of competitors in each new generation; then, to allocate chips that were typically in short supply in the initial months after launch, it employed a specific rationing rule (viz., tying current-period allocations to previous-period purchases) to ensure that its OEM customers would have little incentive to switch their purchases away from Intel; it coupled these moves with an aggressive branding campaign directed at end-users that was further meant to increase switching costs for OEMs; and, last, it made numerous investments in complementary software applications (such as videoconferencing systems) that relied on high-speed chips, so as to stimulate demand for new chips in each generation by making customers feel a continued need to upgrade their computers. As a result of these actions, Intel has consistently ensured that profits from the short time window between product launch and imitation by competitors were more than sufficient to recoup the billions of dollars of capital investment that it incurred in fabrication facilities for each new generation of chips. Indeed, in an industry where patent protection was limited, imitation was fast, and competitors could manufacture at lower cost, Intel continued to be the overwhelmingly dominant supplier of microprocessors, with a market share of almost 90 percent. Of course, Intel did not eschew vigorous legal defense of its intellectual property in keeping would-be infringers at bay. But that was not the sole, or even the primary, line of defense.

Like Intel, companies in other industries have designed ways to repeatedly exploit firstmover advantages across product generations, and thereby extract rents from innovation. 
Consider, for example, Capital One Financial Corporation, one of the most successful credit card issuers over the past decade. Between 1993 and 2000, Capital One introduced new products at an unprecedented rate in the industry, while still maintaining the lowest chargeoffs in the industry. "Of its $\$ 750$ million marketing budget (in 1999), over 55\% was spent on marketing some product that did not exist six months before, $80 \%$ on products that did not exist a year ago, and $95 \%$ on products that did not exist two years before." Moreover, by 1999, the company was performing over 30,000 experiments annually that were aimed at generating new products and services? and all without any patents or formal property rights to protect any of these new ideas! Underlying Capital One's success was its "information-based strategy" (IBS), that entailed an intense use of information on customer behavior to develop detailed credit scoring models, generate new products, and match products with appropriate target customer groups. Imitation by rivals was made even more difficult when one considers the entire set of supporting activities that the firm engaged in to fully exploit IBS, and the manner in which it aligned its entire internal organization to do so. This included creating a novel organizational structure that involved business analysts working cross-functionally, combining authority for credit and pricing decisions into a single division, exploiting IBS not just in product development but in customer service and internal recruiting as well, and developing novel "horizontal accounting" methods for tracking the performance of its products (by customer cohort in addition to product features).

The examples of Intel and Capital One offer a useful lesson on how firms may cope with weak property rights. Each of these companies created, over periods spanning a decade or more, a sustainable means to appropriate value from what were essentially unprotectable innovations. The key was to ensure that its leadership position in one period could be leveraged into a leadership position in subsequent periods, thereby ensuring a first-mover advantage that was repeatable across product generations. Nevertheless, first-mover advantages rely on a longenough time window before the second mover enters. For many products where property rights are weak, such windows are typically much shorter, maybe even negligible. Consider, for example, that test versions of Microsoft's new operating system, XP, were available on the web two months before Microsoft planned to make it available. ${ }^{15}$ Or that, Harry Potter III was available on the same day that it appeared in theaters.

15 "Living with Digital Piracy? Its Been Done Before," by Holman Jenkins, Wall Street Journal, August 22, 2002. 
In other words, both secrecy and first-mover advantages work only if the appropriability problem that it is meant to solve is not too severe after all. In many cases that have received attention recently, the problem of appropriability appears to be more severe. Indeed, time windows before entry of competitors may be hours rather than months, and secrecy or disclosure may be endogenous to the actions of employees rather than of the firms themselves.

Next we consider market-based solutions for overcoming the extreme case of weak property rights? where an asset, once developed by a firm, can be used freely and immediately by others. The strategies considered below may be effective even when the aforementioned ones are not.

\section{III (c). Strategies that Prevent Holdup By Relying on Incentives}

In contrast to strategies that attempt to reduce the possibility of holdup, those discussed in this section work by reducing the incentives for holdup. In other words, there is no presumption that holdup can be prevented or restricted. Instead, holdup does not occur because incentives are set so that it does not pay. The simple model in Section II suggests a natural classification of incentive-based strategies: sticks and carrots.

\section{III (c.i). Sticks: Threats and Reverse Holdup}

The model in Section II suggests that the threat of reverse holdup may mitigate holdup. The relevant tradeoff is in whether or not reductions in future benefits offset the short-term gains from holdup. In practice, firms employ a variety of threats when they deal with suppliers, buyers, or competitors.

Threats to suppliers. The canonical case is holdup by employees. Employees may leave with ideas, knowledge, or relationships that were financed by a firm and join competitors or managing independent firms. Partners from consulting or law firms often leave to start their own boutiques. Successful editors from publishing houses leave and start their own imprints elsewhere or join independent publishing firms. Advertising agencies also have been vulnerable to the loss of client relationships by the departure of key executives. And Silicon Valley is littered with cases of research scientists, software programmers, and engineers leaving large firms to launch their own entrepreneurial ventures. Indeed, a recent McKinsey survey of over 6,000 managers at fifty of the 
largest U.S. firms revealed that " 20 percent of managers said there is a strong chance they will leave their current company in the next two years, and another 28 percent said there is a moderate chance of leaving."

In settings like these, the relevant question is not why holdup occurs, but why it does not occur more often. One reason is that not all the key assets are lost when employee leaves. Projects are often conducted by teams of individuals; research is often done in shared facilities or even common labs; informal channels of communication and interaction between employees occur on a daily basis, giving rise to local spillovers in ideas or knowledge; and relationships with clients are often partly embodied in firms, not just in their employees. In each of these cases, organizations typically retain the ability to develop projects, commercialize ideas, and compete for client relationships even after key employees depart. ${ }^{16}$ But the point is that the threat of competition by the employer can effectively deter holdup in many such cases.

Microsoft shows how companies might use the threat of competition to reduce the rents in the product market to departing employees. Rob Glaser, a ten-year Microsoft veteran, left in 1994 to set up Real Networks and develop software that would enable real-time streaming of audio and video content over the web. Within three years, Microsoft commercialized its own competing product, Windows Media Player. In response, Glaser alleged that Microsoft was competing unfairly by including programming code in its software to disable Real Networks' product, by intentionally ensuring that its own product was unable to play content based on the latest versions of the Real Networks technology, and by refusing to renew its license with Real Networks that would allow it to do so. But the point is that, even without anticompetitive practices, competition itself can work to reduce product market rents to departing employees.

Similarly, publishing houses sometimes find it difficult to retain relationships with wellknown authors whom they have nurtured over many years. In a recent episode, an editor at one of the largest publishing houses recounted:

We were in the midst of renegotiating a contract with one of our authors with whom I had established a relationship more than twenty years ago and published more than fifty of her books. It turned out that another publisher came in and

16 As discussed above, a defining characteristics of "firms" is that there is typically some interaction between employees and across projects, so that the case where assets can be exploited by the firm and not just an employee is likely to be the norm rather than the exception. 
offered her an incredible amount of money. The negotiations got so frustrating that during one of these conversations, I threatened that if she left, we would repackage and publish at least three of her previous books (that we owned the rights to) every single year, in both hardcover and paperback, and not have to put a hand in our wallet to do so. Would we have been able to free-ride on the marketing dollars aimed at supporting her new books? Absolutely. Would this have cannibalized her new books? Maybe, but only to a limited extent. Might it have caused some confusion amongst readers? Maybe in the near term. But the point is that it was enough to convince her to stay.

Threats to buyers. Firms often license or sell the right to commercialize key assets to downstream buyers. Anton and Yao (1994) have elegantly described the holdup problem in these settings:

A buyer may be hesitant to buy or contract for an unknown commodity, but if the inventor first reveals information regarding the invention, a lack of property rights makes it possible for the newly informed party to steal or expropriate the invention.

But even then, the authors argue, the inventor may have a credible threat: reveal the invention to a competing buyer, manufacturer or licensee. This, in turn, would stimulate the original buyer to voluntarily negotiate a contract with the inventor, as the buyer would be concerned about losing its monopoly.

The threat of competition has been effective in extracting value in many different settings. ${ }^{17}$ Indeed, even when buyers are consumers rather than firms, such threats can work. But to be effective, threats must be credible: the firm must be not only able to carry out the threat, but also willing to compete against the buyer. Of course, in equilibrium, threats should dissuade holdup.

17 Brandenburger and Nalebuff (1996) discuss several examples of this general principle, including negotiations between regional utilities and railroads that supply coal, and solicitations of competing bids by a public firm that is a takeover target. Even when a potential entrant has a competitive disadvantage relative to incumbents, the threat of competition can result in substantial gains for the entrant. Consider the production of aspartame, for example. Until the expiration of its patents in 1993, Nutrasweet was a monopolist producer of aspartame in the U.S., and extracted substantial rents from its two major buyers, Coca Cola and Pepsi Co. The entry of Holland Sweetener Company (HSC), even as an unbranded, highcost aspartame producer, was likely to shift the bargaining power substantially. Nutrasweet's value to Coca Cola and Pepsi Co. was now only the incremental benefit above generic aspartame. Indeed, as Brandenburger and Nalebuff argue, "[...] what was left was Nutrasweet's brand equity and manufacturing cost advantage." This in turn would imply that HSC should have been able to extract sizeable rents from Coca Cola and Pepsi Co. before entry even though it had higher costs and its product was unbranded. The reason is simple: the pie would have been no smaller without HSC---it just would have been divided up differently. In other words, as the authors elegantly note, HSC was in a very weak position to sell aspartame, but very strong to sell competition. 
Threats to competitors. Going back to Arrow (1962), competition has been considered anathema to firms that cannot secure property rights. The reason, of course, is that competitors could compete away rents after another firm has sunk its investments. Examples of competitor hold-up include the reverse-engineering of innovations and free-riding on key information. ${ }^{18}$ As discussed earlier, firms that invest in intellectual property, in industries ranging from electronics to computer software, typically have been the focus of many studies. But a similar issue arises in many professional service industries, including advertising, law, and investment banking. In these markets, the key assets typically are embodied in mobile employees. Consequently, the threat that competitors might poach key employees is severe.

Can the threat to retaliate if a competitor exploits key assets or poaches key employees work in these settings? Yes, under certain conditions. First, notice that it consists in competing away the profits to the poaching firm in future periods. In other words, in deciding whether or not to poach, a firm will trade off the increase in profits from poaching or free-riding in the current period with the fall in future profits. This immediately implies that no firm in the industry can be too small, for, if it were, its maximum gains from poaching on others to increase its currentperiod market share will be large relative to the future loss of rents, making poaching attractive. Thus, the smallest firm in the market must be "big enough" to ensure that its future losses are large enough to make poaching unattractive. Interestingly, for a similar reason, no firm in the industry can be too big; otherwise, the other firms' shares will not be big enough to deter poaching. This simple logic suggests that retaliatory threats by firms will be effective only if there are a few firms of similar size. That is, these markets will tend to be natural oligopolies.

\section{Case Study 2: Investment Banks and the Control of Relationships}

The investment banking market offers a natural setting for examining how reverse holdup threats might work, as well as their consequences for the structure of markets. To begin, note the following characteristics of investment banks, their key assets, and investments in these assets. First, Wilhelm and Downing (2001) note, in their comprehensive recent account of the investment

\footnotetext{
18 Gallini and Scotchmer (2002) summarize the argument:

"Competitive markets may not be conducive to innovation, for a reason. [...] Inventions are information, and information is a public good. An invention such as a wireless palmtop is a combination of tangible embodiments and an intangible idea, as well as information about how to manufacture it. Typically, both the information and the tangible embodiments are costly to the inventor, but only the tangible components are costly to a rival. Without some sort of protection or reward, the inventor will therefore be at a market disadvantage relative to rivals, and will possibly be dissuaded from investing."
} 
banking industry, that the services that investment banks offer their clients? including merger and acquisition advice, advice on restructuring deals, equity and debt underwriting, and other advisory services? are "relationship-based, human-capital intensive" (p. 32). Second, Eccles and Crane (1988), in their seminal account of investment banking deals, observe:

[T] he most distinctive [economic characteristic of the investment bank business] is the loose linkage between value provided to customers and fees earned. Investment bankers provide information, advice, ideas, and studies, much of it unsolicited, to both investors and issuers without the firm receiving any direct compensation. Issuers compensate the firm only when a deal is done.

This implies that investments in establishing relationships with clients are sunk at the time of deals, when banks can hope to recoup these investments from deal fees. ${ }^{19}$ Third, relationships between banks and firms need to be considered at both the institutional and individual levels since they reside in both banks and bankers. Indeed, some banks (most recently Deutsche Bank in the 1990s) have periodically attempted to build their client presence in particular areas by simply hiring away staff en masse from other banks. Conversely, the threat of massive poaching can be devastating to a bank's market share. 20

How do investment banks overcome the problem of weak property rights over client relationships? In several ways, argue Wilhelm and Downing (2001). These include the reliance on cooperative arrangements between banks? for example, underwriting syndicates on equity deals, or alliances that maintain online debt platforms. These arrangements limit banks' incentives to free-ride or cheat on each other by holding their feet to the fire in various ways, including the loss of reputation. Another central mechanism that banks use to cope with the holdup problem is the threat of retaliation on competitors? if they were to poach key managers or undercut them on prices. In an insider account of investment banking, Rolfe and Troob (2001) note the prevalence of implicit threats and the lack of price competition:

There has always been an unspoken agreement among the bankers that when it comes to underwritings they won't compete on price. The spreads are sacrosanct. He who cuts spreads will himself become an outcast. The community of investment banks has always been small enough so that if one bank were to break ranks on the pricing issue, the others would quickly join forces and squash the offender. ... Every banker knows that the pricing issue is a slippery slope best avoided because once the price cutting begins, there's no telling where it will end.

Indeed, the consequences of implicit threats are documented in several recent studies of the industry. First, note that, in spite of apparently brutal competition on non-price dimensions, there is virtually no price competition in the industry. This ensures that firms can set prices high enough to recover their upfront investments and overcome otherwise "loose linkage" between fees and costs. Negotiated underwriting syndicates have always superceded competitive bidding for deals, and underwriting fees have, for decades, been virtually unchanged. Indeed, Ritter

19 Interestingly, Eccles and Crane (1988) note that future payment for current advice is not an industry practice that could be easily changed because the value of advice is not known before it is given.

20 As Anand and Galetovic (2000b) note, "In just over a year, Deutsche Bank lured more than 200 employees of other investment banks, including many senior managers." Within a year, the bank claimed that it was the global market share leader in several product areas, where these market shares were assessed purely on the basis of its bankers' relationships with clients and on the deal volume that they had generated in the previous year! 
(2000) reports that, strikingly, 90 percent of initial public offering deals raising between $\$ 20$ and $\$ 80$ million have gross spreads of exactly 7.0 percent.

The market share consequences of such retaliatory threats are also strikingly similar to the simple predictions described earlier in this section. In Anand and Galetovic (2000b), we document market shares of the top banks over four decades and note that they are quite stable. Moreover, no bank is dominant: in every (five-year) period; the industry leader has a market share of less than 20 percent, and the top banks are of similar size. Third, numerous regulatory attempts over several decades to increase competition in the industry have had virtually no effect on aggregate market structure? which is what one would expect if the prevailing market structure were necessary for making key investments rather than merely a convenience to extract market power. And, last, the presence of a large number of small or boutique investment banks has had virtually no impact on the dominant oligopolistic banks? in contrast to the view that they serve as a "competitive fringe" that restrains large bank behavior. The reason is that these two sets of banks serve essentially different markets: large, "bulge bracket" banks serve predominantly large corporations, while small banks serve small firms. In other words, the market is characterized by a "funnel-shaped" structure, with a few very large banks and numerous very small ones.

The evidence suggests that reverse holdup threats can be quite effective in markets where firms deal with a small number of competitors. But, more strikingly, the logic of the argument suggests that, even without regulatory intervention ensuring "small numbers," the voluntary entry and exit of firms can itself ensure that such market structures obtain in equilibrium.

Some of these phenomena described in the context of the investment banking market also can be seen in other intermediation markets? such as law, consulting, and advertising? that display similar characteristics of the underlying production technologies. These are markets in which significant investments are made in assets such as client relationships (that are largely embodied in human capital) over which property rights are weak, and in which investments in these assets are largely sunk at the time of deal pricing. Indeed, what appears to be strikingly similar across each of these markets is that: (i) there is vigorous non-price competition in sales effort, advertising or marketing; (ii) there is limited price competition; (iii) the lack of price competition may be efficient rather than welfare-reducing because it neutralizes another preexisting imperfection, weak property rights; and (iv) the two characteristics of investment banking market structures described above? specifically, the natural oligopoly comprising a few large banks combined with a "funnel-shaped" aggregate market structure? are observed in virtually every one of these other markets, as well.

We have argued here that understanding how firms solve the underlying problem of weak property rights over their key assets in these markets can help to shed light not only on the particular strategies that firms employ in these and related markets, but also on the industrial organization of these markets. A key point is that in each of these settings, either market-based 
strategies, or, as Gallini and Scotchmer (2002) have noted, natural market forces can protect inventors, making formal protections or other incentives unnecessary. Indeed, these arguments suggest that even when legal mechanisms for establishing property rights are ineffective, regulatory intervention to establish monopoly power in these markets may be unnecessary.

\section{$\underline{\text { III (c.ii). Carrots and Complementarities }}$}

In some cases, firms can make holdup relatively less attractive by offering carrots or rewards. Rewards work when the firm can offer a share in a pie that is larger than available elsewhere. Of course, this raises the question: what allows a firm to offer something that is better than the outside option? The answer lies in precisely what makes a "firm" distinctive, its ability to exploit complementarities that come from performing multiple related activities or from owning multiple assets. Thus, the key point is that sometimes complementarities allow firms to offer better carrots to employees, customers or suppliers who might have held them up.

In some cases, complementarities are purely technological. That is, a product or asset may simply not work without its complement. But as Shapiro and Varian (1998, p. 127) point out, in many settings complementarities are entirely a construct of firms' strategies. Gillette, for example, chooses to make its Mach-3 razors compatible with (and thereby a complement to) its own razor blades. Similarly, many firms offer loyalty programs to their customers. By purchasing multiple units from the same firm, the customer is offered the reward of a discount on the bundle, thereby making her purchase of the first unit a complement to her purchase of the second and third and so on. In the same spirit, a firm may offer rewards to key employees or suppliers to retain them. For example, companies often structure compensation contracts that mimic consumer loyalty programs? so that wages might increase well above productivity with tenure, or stock options may vest only after several years.

But more relevant here, complementarities can be intangible as well. Thus, employees may stay on with a firm, even when pecuniary benefits are greater elsewhere, because of personal relationships or the company's unique "culture.” Goldman Sachs, for example, has long been considered the leading investment firm with, as Endlich (2000) puts it, "a solid-gold reputation and a first-class list of clients." Goldman, he argues, could retain talent for a number of reasons. Its partnership status focused the firm on long-term performance; the resulting family feeling and collegial atmosphere separated it from its peers; and the firm's close client contacts not only 
wrought superior information, but allowed it to "control egos and monitor arrogance ... [since] the client, not the salesman, banker, or trader, [was] the focus of any transaction." Industry observers agree with the conclusion that "the firm's culture . . more than anything else, sets it apart from its competitors, making it the organizational glue that induced employees to stick."

This example points to a key lesson about when complementarities are useful to prevent holdup: they cannot be easily available or accessed either through the market or by other firms. In other words, complementarities must be either embedded within an organization or difficult to contract over at arms-length. The reason, quite simply, is that if they were not, then the available surplus would be no different inside and outside the firm, making them useless in preventing holdup.

At first glance, this might seem to imply that firms possessing no particular unique complementary asset are doomed. But that need not be the case. The reason is that, in many settings (including the example of Goldman Sachs), complementarities stem from an entire collection of activities or assets. Hence a firm may have an advantage not only from owning a particular complementary asset or product, but also from coordinating these multiple activities, as the case of International Management Group (IMG) strikingly shows.

\section{Case Study 3: How IMG Exploits Complementarities and Appropriates Value from Mobile Talent $^{21}$}

IMG has been in the business of managing talent? athletes, opera singers, supermodels, authors and speakers? for over forty years. It started as a single-agent-managed firm in 1962 and by 2003 had grown to more than 85 offices and 3,000 employees in 85 countries, establishing itself as the most successful talent management and representation company in the world. Two facts about IMG are striking. First, even though IMG's business exemplifies the hazards of a "free agent nation," relatively few of its customers switch to other firms. Second, IMG's size and scope are quite different from those of similar human-capital-intensive firms. For one, most firms in the business of talent representation in other industries (e.g., Hollywood) appear to be relatively small and specialized. For another, most large professional service firms are owned by partneremployees who appropriate most profits. In stark contrast, IMG is neither a partnership nor small, and its agents are employees. And, it has a strikingly broad vertical and horizontal presence in the value chain.

It is clear that IMG is not intrinsically immune to holdup from employees or competitors. Over the years, sports agents have left IMG, and clients have switched to other firms. For example, in 1992, IMG agents John Simpson and Julian Jacobi left to found Stellar Management

\footnotetext{
21 This section is based on International Management Group, by Bharat Anand, Harvard Business School
} Case Number 702-409. 
because they "didn't have any equity in this business."22 And in 1999, IMG agent Jeffrey Schwarz quit, taking with him three of IMG's tennis stars: Pete Sampras, Martina Hingis, and Marcelo Rios. Similarly, golf stars Nick Faldo, Greg Norman, and Nick Price left IMG at the peak of their success in the 1990s. Moreover, these departures were costly for the firm. One industry expert, following the poaching of classical music singers by different agencies in the 1990s, noted that "it could take ten years for an agent to build a singer's career and another five before star fees come cashing in. . . You lose one artist and you're upset. You lose three stars and you're in trouble." But the question is not why some agents and clients have switched away from IMG over the years, but why so few do. So, how does IMG do it? To understand it, let's focus on IMG's strategy within one of its core businesses, golf.

IMG's prominence in golf began in 1958, when its founder, Mark McCormack, represented golf's biggest star, Arnold Palmer and, within a few years, its other two major stars, Jack Nicklaus and Gary Player. But IMG soon expanded into hosting and managing golf events (starting with the World Match Play Championship in England), then into the design, management, and marketing of golf courses, which was followed by the production and distribution of television programming of golf events, and, finally, by training academies for golfers of different ages. By 2002, IMG had hosted several major golf events, created more than 400 golf courses worldwide, broadcast live international coverage for some of golf's most prestigious events, developed the Sony world ranking system for professional golfers, and run the largest training academies for golf instruction.

At first glance, one might conclude that IMG's "diversifying" moves were intended to reduce its reliance on mobile talent. But, if anything, they made IMG more dependent on stars. To see why, consider, for example, that the most important determinant of a golf event's success is the presence of top stars. In 2000, television audiences for the 17 tournaments played by Tiger Woods (the top-ranked professional golfer) were more than twice as big than those of the 17 events that Woods skipped! In other words, expanding into golf events was likely to increase IMG's vulnerability to holdup. Similarly, production and distribution of television programs was already a relatively mature business at the time of IMG's entry, and IMG did not have any intrinsic skills or expertise at the time. Moreover, neither the logic of training academies as providing an early window on future talent, nor the argument that they might increase the loyalty of future stars (by establishing relationships with them early on), withstand scrutiny. Fewer than 500 golfers participate per year, so academies were unlikely to be an effective way to search for future talent. And, finally, early relationships did not preclude or deter athletes from leaving IMG after rising to stardom. ${ }^{23}$ If anything, establishing relationships early on increased their investments in these relationships and would, therefore, appear to increase the cost from holdup.

It turns out that the main benefit of IMG's diversification was to enhance complementarities with its key asset? talent? thereby enlarging the pie to be shared with them. First, consider golf events. Entry into this activity increased competition for talent by increasing the prize money offered at such events. Moreover, because IMG's clients won approximately 50 percent of all prize money, and the firm received ten percent of their winnings, IMG could afford to offer larger purses than competitors, which in turn offered them an advantage in bidding for the

22 Court documents revealed that agent Jeffrey Schwarz's total compensation from IMG (including salary, bonus, and housing allowance) was slightly over $\$ 160,000$ in 199x, or less than 10\% of IMG's fees from Sampras' endorsements alone. In contrast, note that partners in professional service firms appropriate the entire value created by the firm.

23 In tennis, both Martina Hingis and Anna Kournikova, with whom IMG had established relationships at an early age, left IMG before they had turned 18. 
rights to host these events in the first place. 24 In addition, IMG created various "non-standard" events to showcase their stars (for example, the made-for-TV "Skins" event that featured four prominent golfers competing for exorbitant prize money). And IMG's presence in broadcasting ensured television coverage for these events. Then, IMG would typically grant its "host exemptions" for each event to its own lesser-known golf clients, thereby allowing them access to events that they might not otherwise have. And last, by choosing golf for its events, IMG might favor those courses that had been designed by its own clients (typically, aging golf stars).

IMG's presence in television also offered opportunities to showcase its clients. More favorable scheduling of tee times in golf and match times in tennis? scheduling matches in prime time, on center courts, or as partners with Tiger Woods? may ensure television coverage. Similarly, IMG television crews could make sure that camera angles prominently displayed corporate logos, which, in turn, afforded IMG an advantage in negotiating corporate endorsements for its athletes. 25

Each of these advantages helped increase the "size of the pie." The net result was that the opportunity cost to an athlete of switching away from IMG was considerably increased, thus reducing the risk of holdup. Moreover, even if some stars were to leave IMG, there were large incentives to return. As senior golfers, for example, they might be invited to play with Tiger Woods in a made-for-TV event or have the courses they designed showcased through an IMG event. Indeed, Jack Nicklaus, Nick Faldo and Nick Price returned to IMG as clients after having left the firm years earlier. IMG's unusual success at retaining and managing star talent led to its founder and CEO, Mark McCormack, being named "the most powerful man in sports" in 2002 ? ahead of even the top athletes themselves. IMG itself earned the grudging respect of its competitors, together with such monikers as "I am Greedy," "Incredibly Manipulative Guys," and "I Manage God." As McCormack simply noted, "What we offer are a set of toys that help our athletes, and we have better toys than our competitors."

IMG did not eschew legal defenses, and would often attempt to vigorously defend its noncompete contracts with employees. But, the key point is that by building a vast network of complementary assets and businesses around its clients, IMG simultaneously reduced its vulnerability to personal relationships and holdup by individual sports agents. Indeed, McCormack often observed that "an agent's role was part mentor, advisor, and friend, but an agent remained, ultimately, an employee."

\section{III (d). Strategies that Exploit Weak Property Rights}

\section{III (d.i) Control over Complementary Assets}

The strategies described in the previous section work by preventing holdup. This section discusses strategies that allow firms to appropriate value by exploiting weak property rights over assets that they invest in. The argument is simple and runs as follows. When surpluses are larger

\footnotetext{
24 In 2002, the average purse for an event was \$3.5 million. Since IMG's clients typically win 50\% of prize money, IMG would "get back" approximately $\$ 175,000$ in prize money per event, which afforded them a cost advantage of $5 \%$ in bidding for such events.
} 
elsewhere, it may be difficult to prevent holdup, but sometimes the firm may profit from employees leaving, competitors copying or customers pirating . Why? The central idea rests, as before, on exploiting complementarities with assets or products that the firm can own.

To see this, consider a stylized example. Two products, call them $A$ and $B$ are costless to produce, but the firm has to incur a sunk and fixed upfront cost to "invent" $A$. $A$ and $B$ are complements in consumption, so that $\operatorname{WTP}(A, B)>\mathrm{WTP}(A, 0)+\mathrm{WTP}(0, B) .{ }^{26}$ Let the prices of $A$ and $B$ be denoted by $p_{\mathrm{a}}$ and $p_{\mathrm{b}}$, and demand for each by $D_{\mathrm{a}}\left(p_{\mathrm{a}} ; p_{\mathrm{b}}\right)$ and $D_{\mathrm{b}}\left(p_{\mathrm{b}} ; p_{\mathrm{a}}\right)$.

Now, suppose that consumers can access good $A$ at zero cost (by virtue of cheap copies of $A$, through piracy, or the like). Then, $D_{\mathrm{a}}\left(p_{\mathrm{a}} ; p_{\mathrm{b}}\right)=0$, for any $p_{\mathrm{a}}>0$, and the cost of producing $A$ cannot be recovered. Nevertheless, demand for $B$ would be stimulated if $A$ were available for free. Provided that $p_{\mathrm{b}}>0$,

$p_{\mathrm{b}}^{\prime}=D_{\mathrm{b}}\left(p_{\mathrm{b}} ; c^{\prime}\right) \times p_{\mathrm{b}}>D_{\mathrm{b}}\left(p_{\mathrm{b}} ; p_{\mathrm{a}}\right) \times p_{\mathrm{b}}$

for all $p_{\mathrm{a}}>0$. In other words, $B$ 's profits increase when $A$ is cheap and in some cases may be larger than the cost of inventing $A$. Then there is a straightforward solution to the problem of weak property rights? namely, for a single firm to offer both products $A$ and $B$.

The key assumption is that there exists a complementary product $B$ over which property rights can be established even though they cannot be over product $A$. The following discussion offers examples of where this occurs.

To begin, consider pirated software applications. It is known that in some countries, piracy is rampant, but it less known that even in the United States some 25 percent of all corporate software is purloined, and in other law-abiding Western countries, the figure often approaches 50 percent. Nevertheless, while stand-alone applications like those used as spreadsheets (e.g. Excel or Lotus) or for word processing (e.g., Word or Wordperfect) can be more easily copied and disseminated, the operating system, which is embedded in the computer

25 Note the difficulties in contracting at arms-length in each case. For example, forcing event organizers to use its host exemptions for IMG clients in return for the promise of getting Tiger Woods would be illegal because of "tying".

26 Formally, the WTP function is superadditive in its components. 
microprocessor, is much harder to copy. Of course, if Microsoft were only in the business of developing software applications, it might never do so. But even free software applications cannot be used without the operating system, for which Microsoft can charge a high price. Indeed, as is well known and as our simple model suggests, intense competition and low prices in the software applications market increases demand for the operating system. Thus, Microsoft may want to give away software for free-or train employees who then leave and write programs that use the operating system!

The point is that looking to achieve 100-percent deterrence is not only impossible; it is not even optimal. As a Wall Street Journal article on software piracy noted:

If economic theory has any claim on the real world, Microsoft's pricing should naturally gravitate towards producing an optimum amount of theft. That is, thieves who wouldn't use the product if they had to pay for it, but who might become future customers or who become part of a network of users that makes the software more valuable to legitimate buyers.

Thus free pricing might increase the size of the user network, in turn making the software more valuable to legitimate users. Or, it might induce customers to try a product for free and then end up paying for it in the longer term once they get used to it. These are "complements" in action.

The analogy with free goods suggests a useful lesson. Even if firms cannot retain control of a key asset, they can still capture value by controlling or owning a complementary asset. Consider the impact of biotechnology on pharmaceutical companies since circa 1980. Changes in the technology of drug discovery---from large scale trial and error methods to systematic drug design---made it easy, even efficient, for small biotechnology firms to compete in research with pharmaceutical giants, as the key asset shifted from financial or physical capital to human capital. Indeed, many biotechnology firms trace their roots to these large pharmaceutical companies themselves, as hundreds of scientists left to start or join small companies since the larger ones no longer had an advantage in retaining key talent. Strikingly, however, pharmaceutical giants have earned most profits in the industry over the past two decades, and their average returns on equity have remained amongst the highest in the economy. The reason? Even though pharmaceutical firms no longer controlled a key asset--- research talent---they still owned the key complementary assets needed to commercialize drugs: the large distribution facilities and marketing networks. 
Complementary assets need not be physical or tangible. Control or ownership of complements that are intangible suffice. One common case is the provision of services. For example, many software firms price their software applications for free, and aim to generate profits by offering complementary products or services that customers value. Netscape, for example, made its browser available for free to most individuals, but charged corporations for the more complex Web server versions of the browser. ${ }^{27}$ A recent example is the open source software market where firms like Red Hat and VA Linux specialize in commercializing Linux, an open source UNIX-based operating system that is freely available. Lerner and Tirole (2002) note that:

Red Hat provides support for Linux-based products, while VA Linux provides hardware products optimized for the Linux environment. (They) exemplify the strategy of commercially providing complementary services and products that are not supplied efficiently by the open source community. (Thus,) while improvements in the open source software are not appropriable, commercial companies can benefit indirectly in a complementary proprietary segment.

The example of pharmaceutical companies illustrates that firms who own key complements can benefit even when key employees leave. Consider the case of McKinsey. At first glance, its hiring and training policy appear puzzling. Every year, it recruits in droves, then forces out large numbers of these same hires after a few years. But, as The Economist notes, the vast old-boy network of McKinsey has its own benefits: "The flow of individuals from firms to clients, and back again, is continuous and intensive", with the result that McKinsey alumni would typically be more inclined to "call upon former colleagues to provide services for their new employers." 28 In other words, ownership of the McKinsey name and its associated reputation--the complementary asset to mobile human capital---allows the firm to act as a broker of valuable relationships amongst those who benefit from the name.

\footnotetext{
${ }^{27}$ As Netscape co-founder Marc Andressen noted: "A lot of companies who are going to use it are going to pay for it, because among other things they want to pay for it. Free software is usually more expensive in the long run for companies to use." In The Browser Wars, 1994-98, by David Yoffie and Mary Kwak, Harvard Business School Case No. 9-798-094..

28 "Spoilt For Choice", The Economist, July 5, 2001. The article also notes that "McKinsey's old-boy network is the envy of all. Its role call of chief executives includes Lou Gerstner of IBM, Harvey Golub of American Express, Lukas Muhlemann of Credit Suisse, Jeffrey Skilling of Enron, and Anton van Rossum of Fortis, to name a few. The power of the service firms' old-boy networks increases exponentially. . . . A slight variation on (Metcalfe's Law) can be applied to old-boy networks: their value grows in relation to the square of the number of former employees working for clients, and their elevation in the corporate hierarchy."
} 
Revenue models that rely on complementary assets come in different forms. Consider, for example, various types of online entertainment content---short films, music videos, or cartoons--that are relatively easily pirated. At first glance, it would appear difficult to bundle these types of content with complementary products that consumers would value. But, even when complements do not benefits primary consumers directly, bundling assets and their complements can benefit third parties. For example, television networks bundle products that consumers want (television shows) with products that consumers dislike (advertisements), and the benefits from this bundle are then captured by charging advertisers for the access to captive consumers.

As these examples illustrate, adopting strategies that exploit weak property rights may change the boundaries and scope of a firm. Expanding the set of assets that are owned or controlled allows firms to price bundles more accurately, to enhance coordination, or to exploit complementarities across products. But, in addition, diversification and scope expansion works by increasing reliance on the core asset, not by attempting to diversify revenue streams. The premise that underlies strategies that exploit weak property rights is to generate revenues from investments in core assets.

The examples suggest another necessary condition for these strategies to work:, firms must have some market power in the complementary asset market. Excess profits from the complementary asset can then be used to recover investments in assets or products that the firm cannot own. By implication, "carrots" are ineffective when there exists competition in the market for complementary assets.

\section{Application: Strategies to Cope with Piracy in the Music Industry}

Perhaps no industry has seemed more vulnerable to weak property rights than music in recent years. The 1990s saw the development of new technologies for compressing, storing, and playing music over the Internet, which, in turn, spawned websites that facilitated peer-to-peer file sharing on an unimaginable scale. The first such site, Napster, was founded in early 1999, and by the end of the year users could access over 450,000 songs free of charge (Anand and Cantillon, 2003). The popularity of file sharing caused great concern in the music industry because of its potential deleterious impact on CD sales and industry profits. 
In this section, we use our framework to explore strategies that may work in the music industry and discard those that probably will not. Our aim is not to make predictions on how the industry will evolve (although we do to some extent), but to use the framework developed in earlier sections to organize the evidence, interpret various events, and shed light on what strategies may work. In the process, we critically examine the popular view that there has been "a fundamental collapse of the music business." ${ }^{29} \mathrm{We}$ also examine the alleged ineptitude of record companies in devising strategies to cope with piracy. Our analysis suggests reason to doubt both these suppositions.

\section{IV (a). Strategies that May Prevent Holdup and Piracy}

\section{IV(a.i) The legal and technological fix: limits and some opportunities}

The recording industry's first reaction was to file a lawsuit against Napster for aiding the infringement of copyrights. In December 1999, the Recording Industry Association of America (RIAA) filed suit on behalf of 18 major record companies (including Bertelsmann, EMI, Sony, Universal, and Warner). After several months of legal wrangling, the Federal Court ruled in February 2001 that Napster could no longer allow its users to swap files of copyrighted music, and the company shut down its site and filed for bankruptcy in June 2002. The record companies' next line of defense was to devise technical solutions that could halt online file-sharing. Examples of such solutions included copy-protected CDs that prevented the copying of files, "digital watermarks" that were invisible markers aimed at tracking file movements and limiting reproduction, and even encryption chips embedded in PCs and other devices that might allow for stronger protection.

As in other sectors, however, neither legal remedies nor anti-piracy technologies were very successful, and by the time music companies succeeded in shutting down Napster, numerous file-sharing sites, such as Gnutella, KaZaa, and Morpheus, had already replaced it. Unlike Napster, though, they did not store files in a central server but offered software that allowed users to search and access files stored on personal computers. Not surprisingly, legal actions became more difficult. In 2001, a Dutch court ruled that Kazaa was not liable for copyright infringements

\footnotetext{
29 "This is War: Should the Computer Industry Protect Hollywood from Digital Theft?" Fortune (2002), 145 (11), 27 May.
} 
committed by its users, foreshadowing the difficulty that record companies in the United States may face in the courts. ${ }^{30}$ This series of events led an industry observer to note:

[W]hile the entertainment industry may be winning most of its legal battles, it seems to be losing the war. ... [T] he startling truth [is] that downloading of music, and now films, continues unabated despite the myriad lawsuits. ${ }^{31}$

Neither were technical solutions successful, either because of technical limitations (e.g., some copy-protected CDs could not be played on computers, DVD players, game consoles, and MP3 players) or, more importantly, because they could be circumvented as programmers broke codes regularly. According to a recent account ${ }^{32}$ :

In Silicon Valley, copy protection is seen as folly. Not only do geeks treat code cracking as a contact sport, but the software industry has been trying? and failing? to combat piracy for years. ... When the [music] industry came up with a supposedly secure format called SDMI, it took Princeton computer-science professor Edward Felten only two weeks to crack it.

More fundamentally, as the Wall Street Journal argued:

A technical fix for piracy was never on the cards. The software code to break DVD encryption has been perfected to the point where it fits on a T-shirt. The music industry's own proudly proclaimed digital watermark was busted in three weeks by four different groups. Now a Dutch cryptographer claims to have found "a fatal flaw" in Intel's design to stop digital broadcasts from being copied and redistributed on the web. That leaves only a business solution.

Apple Computer's CEO Steve Jobs summarized the inherent limits of legal and technological strategies when he argued that "[p]iracy is a behavioral issue, not a technological one." 33

Yet selective legal and technological strategies may be of some help, as recent actions by record companies suggest. First, they targeted heavy file-sharing users, suing four students from reputed universities? very publicly. Second, realizing that suing each of the millions who occasionally download a song would be fruitless, they targeted firms that either directly or indirectly facilitated piracy. Specifically, they sent "warning letters to major U.S. companies and

\footnotetext{
30 "E-Commerce: A Special Report”, Wall Street Journal (2003), 27 January.

31 Wall Street Journal (2003), op.cit.

32 See "Burn, Baby, Burn,” Time (2002), 159 (20), 20 May.

33 Time, op. cit.
} 
universities urging them to cut down on file-swapping"34 by employees or students. Next, they turned their attention to the financiers of firms that developed file-sharing technologies. For example, Universal Music Group sued a leading venture capital firm for its investment in Napster on the grounds that its financial support allegedly contributed to copyright infringement. Last, the RIAA looked to subpoena Internet access providers, in order to obtain the names of customers who had illegally downloaded hundreds of music files. Each of these strategies delegated the task of monitoring illegal downloading and file-sharing to firms that had the ability to do so.

\section{$\underline{\text { IV(a.ii) Sticks and carrots: can they work? }}$}

Can music companies use sticks or carrots to deal with weak property rights and piracy? Our model suggests some limitations. First, consider sticks. The model presented in Section II suggests that sticks work because spillovers enable the "corporation" (here, the studios) to threaten the "researcher" (here, the pirates) with intense market competition if she decides to leave. But, with piracy, competition is not much of a threat because music is available for free anyway! Thus sticks can work only if record companies directly harm pirates.

To some extent, record companies have tried to do just that by engaging in a sort of guerrilla warfare against selected pirates. For example, users who attempt to download the latest songs by rap artist Eminem may obtain empty files or files with bogus tunes that were dumped onto several file-sharing networks and disguised as legitimate tunes. Or these users might be automatically redirected to websites where they could legitimately download the songs (for a fee). Other tactics were more insidious. For example, it was alleged that all five major music record labels contacted several small software companies in California to develop software that might disable the computers of individuals who were suspected of downloading files without permission. This software included viruses, hunter bots, or programs that would freeze the users' Internet connections or freeze their personal computers directly. As recently noted, these tactics

... could be more successful than suing the companies involved since it strikes at the hearts of consumers whose actions on the Internet . . . are measured more by convenience than free or not free. Make it difficult, frustrating, or risky to get the song you want, and, chances are, you'll think twice before venturing onto Morpheus. ${ }^{35}$

Note that record companies are taking advantage of a key "spillover": they manufacture the master copy that is pirated, and so are, in principle, able to introduce devices to harm pirates.

\footnotetext{
34 "Judge Orders Verizon to Name Song-Swapper," The Wall Street Journal (2003), 22 January.
} 
Now consider carrots. In the model, they work because the corporation exploits complementarities, enlarges the pie and offers a better deal to the researcher. The fundamental limitation of carrots in the music industry is that music can be consumed independently, and it is not obvious which other goods or services controlled by the studios may be used to create complementarities that can be accessed only by buying from them.

Music studios have begun to take actions that may be intended to take advantage of complementarities. Thus Vivendi Universal acquired EMusic.com, the first commercial site that offered customers a downloadable music subscription service. Soon after that, other music majors (BMG, Warner, and EMI) launched MusicNet, which licensed to several distribution partners (AOL and Real Networks) both its music content and the technology for streaming, downloading, and burning music. Then, Universal and Sony launched Pressplay, another online subscriptionbased service. (More recently, technology providers like Apple launched online commercial services with more success. Later, we discuss reasons for the differential success of these different online ventures).

Relatedly, record companies began bundling CDs with other low-cost complementary products or services on which consumers placed substantial value. This made it worthwhile to purchase the $\mathrm{CD}$ rather than download it illegally and forego the sweeteners. For example, the band Bon Jovi hoped to establish a serial relationship with fans, offering extras such as preference in buying concert tickets, the possibility to climb on stage, and the possibility to chat with the group online. Similarly, Interscope Records (part of Universal) included a free DVD with the first two million copies of the new Eminem album. ${ }^{36}$

So, how effective can carrots be? As seen, they hold some promise, but a caveat is in order since it is unclear whether these are truly carrots as we have defined the term here. The key issue is whether the sweeteners are either cheaper or more attractive because they are sold together with records. Otherwise, the critical reader may observe, record companies may as well charge directly for the sweetener.

\footnotetext{
35 "Fake Files, User Caps Hit Music Swappers," The Toronto Star (2002), 17 June.

${ }^{36}$ See "Music Industry Hopes Exclusives Can Blow Pirates Out of the Water," Wall Street Journal (2002), 16 September.
} 


\section{IV (b) Exploiting Weak Property Rights: Redefining the Boundaries of Music Firms}

Several critics of the record companies have argued that they should embrace free music rather than fight it. But this, of course, raises a question: demand for music may increase because it is freely available, but how can record companies capture any value from a free good? The answer is by reaping profits from complements, those activities and goods that become more valuable when music is free. As we will see next, this is perhaps the most effective strategy to cope with piracy, but it may require firms' boundaries to change.

A cursory analysis suggests a broad range of such complements: music concerts, artist merchandise, MP3 players, storage devices, personal computers, high-speed Internet access, and so on. Clearly, producers of complementary products and services might benefit from free music even while producers of music content lose. Early evidence appears to bear this out in striking fashion. ${ }^{37}$ For example, in 2001, unit sales of blank CDs (1.1 billion) exceeded sales of prerecorded CDs (968 million) for the first time. In the same year, there was a 90-percent rise in the number of computer owners with a CD burner. A third of all PCs have one; 54 percent of new computers come with one installed. Similarly, in 2001, sales of CD burners rose by 14 percent, to $\$ 684$ million. Moreover, the number of portable MP3 players (such as Apple's iPod) more than doubled in the previous two years. And, according to Fortune,

... companies like Intel and Microsoft are eager to get a wide variety of movies online because they believe films will drive the large-scale adoption of broadband and help the PC become the center of the home entertainment network. ${ }^{38}$

Indeed, when the RIAA objected to an advertisement by Gateway Computers that appeared to condone CD burning, the company “. . . happily conceded that CD burning was a cash cow." Taken together, the implication is clear. The sales of music and its complementary products and services may have actually increased, not declined, in recent years. ${ }^{39}$

\footnotetext{
${ }^{37}$ See “Burned?" Boston Globe (2002), 12 May; “Burn, Baby, Burn”, Time (2002), 20 May.

38 "This is War: Should the Computer Industry Protect Hollywood from Digital Theft?" Fortune (2002), 145(11), 27 May.

${ }^{39}$ As the President of New Media for Universal Records notes, "I find it incredibly ironic that some people will spend an extra $\$ 1,000$ on their hard drives just so they can store more music, but they won't pay for music" (“Burned?" Boston Globe (2002), May 12).
} 
All this implies that the main challenge facing record companies, then, is not necessarily how to increase the music pie, but how to redistribute it. Indeed, the conflicting objectives between record companies and companies in the "complement" business have been revealed through their actions in recent years? specifically, on whether to fight piracy or to embrace it. Consider, for example, that when several record companies served a subpoena on the Internet service division of Verizon, asking for the names of two customers the RIAA claims downloaded hundreds of music files without authorization, Verizon chose to appeal the ruling:

[T] he ruling set too low a standard for the circumstances under which it would have to turn over the name of a customer, because a copyright holder wouldn't have to file suit against unidentified peer-to-peer users before obtaining their identities. ${ }^{40}$

It might be tempting to attribute Verizon's stance to its objective of protecting privacy, but the differences between the objectives of the content and technology companies came into sharper relief when, not coincidentally,

... the record labels drew backing from the Motion Picture Association of America, which fears that movies could soon be widely swapped online. For its part, Verizon drew supportive briefs from an array of technology interests, including the U.S. Internet Service Providers Association, which includes EarthLink Inc. and AOL Time Warner Inc.'s America Online unit! ${ }^{41}$

Record companies and movie studios recognize these differences in incentives. In his 2002 testimony on a bill before the U.S. Senate that would order the FCC to find a way to stem piracy if the firms in the entertainment and related sectors could not devise effective solutions on their own, Disney CEO Michael Eisner bashed Silicon Valley: "We're dealing with an industry where an unspoken strategy is that the killer app is piracy." 42 Interestingly, the same bill was "anathema to technology leaders like Intel Chairman Andy Grove and Apple Computer CEO Steve Jobs. ${ }^{43}$

\footnotetext{
40 "Judge Orders Verizon to Name Song-Swapper," The Wall Street Journal (2003), 22 January.

41 "Judge Orders Verizon to Name Song-Swapper," Wall Street Journal (2003), 22 January.

${ }^{42}$ See "This is War: Should the Computer Industry Protect Hollywood from Digital Theft?" Fortune (2002), 145(11), 27 May. His comments were echoed in a recent article on piracy that observed that file sharing services "[...] are the killer apps of the broadband computing world."

${ }^{43}$ Fortune, op.cit. The article also cites an op-ed piece in which Grove questioned the logic of regulatory intervention, and the incentives of the entertainment companies in fighting technological change rather than embracing it: "Were the manufacturers of printing presses forced to protect the monks? Was the PC industry forced to protect the mainframe industry? Why is this case any different?...The message is clear:
} 
But how might record companies establish claims over the new pie? There appear to be at least three ways to do so: (i) acquiring companies that own the complements or being acquired by one; (ii) establishing or renegotiating contracts with such companies either directly ${ }^{44}$ or indirectly ${ }^{45}$; and (iii) entering these markets themselves.

Some companies? such as Sony (with Sony Music and Sony Electronics) and AOL Time Warner (with Time Warner Music and Time Warner Cable)? already have an existing stake in both music content and its complementary technologies or products. This results in interdivisional conflicts or coalitions within the same firm that find themselves on opposite sides in the battle against piracy. ${ }^{46}$ Others, such as Bertelsmann, have sought to increase their presence in the complementary parts of the value chain even while their music divisions were combating piracy, leading to inevitable conflicts between music divisions and corporate headquarters. The key point is that, just as the availability of free music has reconfigured the music pie by shifting value from producers of music content to producers of music complements, it will probably reconfigure the scope of operations of record companies, as well. Moreover, because, as we have argued here, any eventual solution will involve some redistribution or reallocation of claims between existing firms over the music pie, the transition is likely to be marked by conflicts. ${ }^{47}$

the studio owners are dinosaurs. If they can't adapt the to the brave new world the companies like Intel and Apple have ushered in, extinction is what they deserve." In response, one observer simply noted: "Grove has a point. But so do Hollywood executives who accuse their Silicon Valley counterparts of ignoring Internet piracy because it helps them sell gadgets".

${ }^{44}$ One example might include renegotiating contracts with MTV and other promotional channels benefit from an increase in the demand for music by listeners, but (as in the case of MTV) obtain music videos for free from the record companies.

${ }^{45}$ One example may include lobbying for a tax increase on blank CD sales, whose revenues would flow back to the record companies.

${ }^{46}$ Interestingly, the aforementioned Senate bill was endorsed by movie studios from Disney, News Corporation, and Viacom, whereas it was "supported somewhat less enthusiastically by AOL Time Warner CEO Richard Parsons and Sony Corp. of America CEO Howard Stringer." ("This is War: Should the Computer Industry Protect Hollywood from Digital Theft?” Fortune (2002), 145 (11), 27 May.

${ }^{47}$ Conflicts between owners of content and owners of complements are not recent. Indeed, as one observer noted:

"The entertainment industry has been engaged in a reactive struggle against new technologies for most of the last century, sometimes succeeding in the legal battle but ultimately unable to stop technology's advance. Often surprisingly, the technologies that copyright holders initially sought to suppress were eventually embraced as an integral part of their business. The owner of sheet music copyrights sued the maker of piano rolls used in player pianos. A music producer sued a radio station over its broadcasts when radio threatened the traditional music copyright model. A movie studio sued a fledgling cable television operator for rebroadcasting television signals. More recently, a motion picture company filed a claim against a VCR manufacturer, adding another technological advance to the litany of inventions predicted to 
Either way, the music industry will survive simply because, as noted in Fortune (May 27, 2002), “. . . unless somebody flinches, both sides stand to lose."48

\section{IV (c) Ineptitude Versus Incentives}

Many have argued that record companies have been inept in coping with piracy. Indeed, their online ventures were, at least in the near term, failures. Within a few weeks of the launch of MusicNet, its CEO declared that the current version of the service was not viable. In diagnosing the reasons for failure, The Wall Street Journal noted:

It isn't hard to see why. [They] created a service that lacked just about everything that makes online music downloads appealing. It didn't allow consumers to keep downloaded songs permanently. It didn't allow them to transfer songs to portable devices or exchange them with friends who weren't signed up to the service. And it charged a monthly fee. Renegade Internet services allow all that and more, for no charge. ${ }^{49}$

Indeed, it was clear from the outset that, when it came to the commercial online music services of the record companies, the "online pricing is way off. The reason: companies look at an online customer as a threat, someone who might stop buying CDs. So they try to set the price at nearly the $\mathrm{CD}$ level, even though the costs of online delivery are negligible." 50

doom intellectual property rights. In each case, content owners eventually embraced the new technology they originally opposed."

Raysman and Brown (2000) note that:

"although the relationship between file sharing and large companies is antagonistic right now, history suggests that this new method of content distribution may be a significant commercial opportunity for the recording industry. [...] The industry needs to look back only to the early 1980s, when Universal City Studios sued Sony for manufacturing videotape recorders, which Universal perceived as a threat to its movie business. The decision initially startled the movie industry, but its effect turned out to be positive: today, revenue from video rentals comprises a substantial share of total movie studio revenues. Similarly, baseball teams initially protested free radio broadcasts of their teams' games, fearing the listening audience would cannibalize ticket sales. Today, revenue from television and radio broadcasting dwarfs that of tickets."

${ }^{48}$ See "This is War: Should the Computer Industry Protect Hollywood from Digital Theft?" Fortune (2002), 145 (11), 27 May. As the Wall Street Journal recently speculated, "eventually, the music companies and consumer electronic companies need to join forces. There's even been whistling that Apple or Microsoft might buy a music company."

49 "Off-Key: The Music Industry is Finally Online, But Few Listen," The Wall Street Journal (2002), 7 May.

50 “Digital Media: Don't Clamp Down Too Hard,” Business Week (2002), 14 October. 
In stark contrast, Apple Computer launched its own commercial online service, iTunes, in April 2003 and allowed users to legally download songs at a price of $\$ 0.99$ per song. Although, at first glance, the price of downloading ten songs might not appear too different from that of buying a ten-song CD in a store, Apple's program included several attractive features. First, in contrast to the terms offered by record companies on their websites that allowed legal downloads, consumers could now listen to a downloaded song an unlimited number of times. Second, consumers had the right to listen to the song on upto three computers and to legally burn it on an unlimited number of CDs. Third, all five major music labels licensed their content to Apple, resulting in a menu of over 200,000 songs. Finally, the variable pricing model meant that, like other file-sharing sites, consumers did not have to pay an upfront subscription fee. During the first week after launch, there were over one million downloads, or an increase in online music purchases of almost one million dollars. ${ }^{51}$

Indeed, based on their differing records in developing commercial alternatives to free online music, the conventional wisdom is that " . . the recording industry has . . been notable mainly for clumsiness, proprietary paranoia, and a condescending attitude towards its customers." In contrast, technology companies have been perceived as forward-thinking, fast-moving, and entrepreneurial. ${ }^{52}$ Our analysis suggests a reason for caution because the differences in success may simply reflect differences in incentives, not simply in aptitude or creative genius. On the one hand, record companies had every incentive not to make downloading truly viable because its first-order impact would have been to accelerate the trend towards free music, thereby cannibalizing offline revenues. On the other hand, as a producer of computers, CD burners, and MP3 players, whose revenues were propped up by all forms of music downloading and sharing, Apple had incentives to encourage the trend towards cheap and ubiquitously available music. As an industry observer noted: "In many ways, [Apple's] business model for the iTunes service is very closely aligned to that of the online pirates they're so desperate to destroy."

\section{Conclusion: Three Lessons for Managers}

\footnotetext{
51 See "Copy Cat Culture", Business and Finance (2002): 33.

52 The New York Times ("Downloading Music Over the Internet Without Feeling Like A Criminal", June 7, 2003) noted that "[...] it is ironic that Apple should have introduced the first really successful commercial Internet music service," in contrast to the record industry that had contrived to "alienate its ideal audience--young people who live and breathe music---by being way behind the technological curve and by repeatedly sounding as if its main job was law enforcement rather than selling music."
} 
We started by arguing that weak property rights over assets and ideas have not deterred firms from investing in them. We conclude with three lessons for managers.

\section{Coping with weak property rights through the law or the market. The usual}

presumption is that the problems caused by weak property rights can be solved by toughening the law and its enforcement. Thus it is often argued that piracy, illegal copying, or rights infringement must imply, inter alia, that the laws to establish and enforce property rights are either not strong enough or not enforced.

But when it comes to appropriating value from investments in certain types of assets, legal means may be inadequate. Weak property rights may just reflect that it is impossible to establish or enforce such laws. At the same time, this does not mean that firms are helpless to recover their investments in such assets. The point is that, in many cases, it may be more productive to search for solutions that rely on the market rather than focusing effort and attention on legal strategies. ${ }^{53} \mathrm{We}$ have argued that, in these cases, strategies that work through incentives can substitute quite effectively for formal mechanisms that work through fiat. ${ }^{54}$

It is worth noting that firms entering or doing business in many emerging markets face challenges of weak or insecure property rights as well. Consequently, the types of strategies described in this paper are likely to resonate in those markets as well. However, there is one fundamental difference. In the settings that we have described in this paper, weak property rights are more sensibly viewed as a primitive of the contracting environment rather than a consequence of intentional design. In contrast, the differences in strength of property rights between emerging and developed markets are more likely endogenous to the actions of host regimes (and surely over the longer term). Moreover, property rights in those markets are insecure in general, and not only for knowledge and information.

\footnotetext{
${ }^{53}$ In their survey analysis of protection for intellectual property, Levin et al. (1987) similarly conclude: "Since the impact of legal protection of intellectual property...varies widely among industries, focused efforts to solve problems in specific markets would be more prudent than a broad attempt to upgrade protection. There is little point in expending diplomatic capital to compel foreign countries to pass or enforce laws that, in most industries, would have minimal impact on the competitive process."

54 Boldrin and Levine (2003) take this logic a step further to make a case against "intellectual monopoly" rights. They argue that even when legal mechanisms are effective, granting monopoly rights to inventors may be unnecessary since, in practice, they can often devise ways of recouping the investments in their
} 
2. Type 1 errors: overstating the scope of the problem. As seen here, numerous firms have designed solutions to cope effectively with weak property rights. In spite of this, many firms that are challenged by weak property rights often think that they are unable to cope. Why do firms typically overstate the scope of the problem ("type 1 errors") and find it difficult to identify solutions that can circumscribe weak property rights and reduce their vulnerability to holdup? Indeed, can firms avoid this type of error?

One answer is that they have incentives to do so. Overstating the threats is one form of lobbying and can be an effective strategy to rally sympathetic lawmakers. But, too often, firms genuinely believe that they have no other recourse when, in fact, they might. Indeed, we believe that framing the problem too narrowly often tends to limit the search for effective answers. To see this, recall that the music studios' initial (and pessimistic) response to illegal file sharing was to argue that a resulting five-percent drop in CD sales would serve to wipe out their entire profits. And correctly so? if they continued to rely on CD sales for the bulk of their profits! As seen, however, effective solutions often require firms to change their existing strategies, their existing activities, and maybe even their existing boundaries. In the future, it would not be surprising for record companies to own or be owned by corporations selling goods or investing in assets that are complements of music.

Recall that an effective strategy for firms to overcome holdup, imitation, or piracy of key assets is to own or control complementary assets (just like firms that intentionally give away a product for free to make money from sales of another). Firms spend R\&D dollars on open-source software, knowing that they can extract revenues on related consulting services. Netscape voluntarily priced its browser for free? knowing that this might increase demand for web servers by corporations from whom they could generate revenues. And Microsoft spent millions of dollars to develop a competitive product to Real Network's software for live streaming of audio and video content, then gave it away for free. Why? Because such software applications would only enhance the value of its operating system where it made money. In each case, the firm managed to reduce its reliance on a key asset or product by expanding its scope of activities, so that it could control or own additional complementary assets and products. And, in each case, the argument that weak property rights make it impossible to capture profits from the relevant asset or product would have missed the possibility that a firm may capture rents on complementary

innovation. Focusing on the benefits of first-mover advantage, they note that "ultimately no academic work can do more than scratch the surface of (this) advantage: it is limited only by human ingenuity." 
assets or products, or elsewhere in the value chain. The point is that looking for solutions using a piecemeal approach can overemphasize the costs of holdup and miss feasible solutions.

\section{Type 2 errors: believing that weak property rights are not a problem. In contrast to}

type 1 errors described above, firms sometimes fall into the opposite trap and underestimate the problem. Consider a simple example. Suppose that one observes a given market and sees firms regularly making large investments in assets they cannot legally own and that generate substantial profits. Seeing this, one may incorrectly conclude that either property rights over these assets must be reasonably secure or that weak property rights are not a problem after all. The logical flaw, of course, is to omit that the observed outcomes may reflect effective strategies rather than effective property rights. Consequently, in such markets, one should ask a simple but central question: are weak property rights not a concern per se, or aren't they a concern in equilibrium?

Consider the following examples. Book authors rarely switch between publishing houses when it comes time to renegotiate contracts for future book deals. Entrepreneurs who receive funding offers from a particular venture capitalist rarely end up switching financiers to get better terms elsewhere. Athletes who are nurtured from an early age by particular agents or sports marketing companies rarely switch to others later on when they become stars. One might incorrectly conclude that in each case switching costs between firms are high. However, as should be clear from our cases, firms typically design smart strategies to ensure that holdup is mitigated and switching costs are high in equilibrium. Consequently, understanding the nature and impact of firms' actions can be central to understanding whether property rights are intrinsically secure or de facto adequate. 55

\footnotetext{
${ }^{55}$ Note that similar problems might arise with surveys or questionnaires as well. Summarizing the results of their survey analysis of managers in 45 industries about the effectiveness of protection afforded by patent laws for innovations, Levin et al (1987) noted that "a respondent's perception... may also be affected by his firm's policies or strategies."
} 


\section{References}

Alchian, A., 1967 “Property Rights.” The Concise Encyclopedia of Economics

Anand, B. and K. Attea, 2002. "International Management Group." Harvard Business School. Case Number 9-702-409

Anand, B. and E. Cantillon, 2003. "The Music Industry and the Internet." Harvard Business School. Case Number 9-703-513

Anand, B. and A. Galetovic, 2000a, "Weak Property Rights and Holdup in R\&D," Journal of Economics and Management Strategy Vol. 9, pp. 615-642

Anand, B. and A. Galetovic, 2000b, "Information, Non-excludability and Financial Market Structure," Journal of Business Vol. 73, pp. 357-402

Anand, B., A. Galetovic and A. Stein, 2003, "Incentives versus Synergies in the Market for Talent," work in progress, CEA and Harvard Business School

Anand, B. and T. Khanna, 2000. "The Structure of Licensing Contracts," Journal of Industrial Economics Vol. 47, pp. 103-135

Anand, B., M.G. Rukstad and C.H. Paige, 2000. "Capital One Financial Corp.” Harvard Business School Case Number 9-700-124

Anton, J. and D. Yao, 1994. "Expropriations and Inventions: Appropriable Rents in the Absence of Property Rights,” American Economic Review Vol. 84, 190-209

Anton, J. and D. Yao, 2002. "The Sale of Ideas: Strategic Disclosure, Property Rights, and Contracting." Review of Economic Studies, Vol. 69, pp. 513-531

Anton, J. and D. Yao, 2003. "Attracting Skeptical Buyers”. Wharton School Working Paper.

Arrow, K., 1962, "Economic Welfare and the Allocation of Resources for Innovation." in R. Nelson (ed.) The Rate and Direction of Inventive Activity. Princeton: Princeton University Press.

Bhattacharyya, S. and V. Nanda, 2000. "Client discretion, switching costs, and financial innovation." Review of Financial Studies, Vol. 13: pp. 1101-1127

Bhide, A., 1994, "How Entrepreneurs Craft Strategies That Work." Harvard Business Review, Reprint \#94202

Boldrin, M. and D. K. Levine, 2003. The Case Against Intellectual Monopoly. Manuscript in progress

Brandenburger, A. M. and B. J. Nalebuff, 1996. Co-Opetition: A Revolutionary Mindset That Combines Competition and Co-Operation: The Game Theory Strategy That's Changing the Game of Business, New York: Doubleday

Casadesus-Masanell, R., D. Yoffie and S. Mattu. 2002. "Intel Corp. - 1968-2003.” Harvard Business School. Case Number 9-703-427 
Cohen, W., R. Nelson, and J. Walsh, 2000, "Protecting Their Intellectual Assets: Appropriability Conditions and Why U.S. Manufacturing Firms Patent (Or Not). "National Bureau of Economic Research Working Paper No. 7552.

Eccles, R., and D. Crane, 1988, Doing Deals: Investment Banks at Work. Boston: Harvard Business School Press

Endlich, L., 2000, Goldman Sachs: The Culture of Success. New York: Touchstone Books.

Gallini, N. and S. Scotchmer, 2002. "Intellectual Property: When is it the Best Incentive System?" in A. Jaffe, J. Lerner and S. Stern (eds), Innovation Policy and the Economy, Vol 2. Cambridge: MIT Press

Ham, S. and R. Atkinson, 2000. "Napster and Online Piracy: The Need to Revisit the Digital Millennium Copyright Act." E-Business Law Bulletin. Vol. 1,

Hart, O. and J. Moore, 1994. "A Theory of Debt Based in the Inalienability of Human Capital," Quarterly Journal of Economics, Vol. 109, 841-879

Holmstrom, B., 1989. “Agency Costs and Innovation,” Journal of Economic Behavior and Organization Vol. 12, pp. 305-327

Horstmann, I., A. Slivinski and G. MacDonald, 1985. "Patents as Information Transfer Mechanisms: To Patent or (Maybe) Not to Patent." Journal of Political Economy, Vol. 93 pp. 837-858.

Langenderfer, J. and D. L. Cook, 2001. "Copyright policies and issues raised by A\&M Records v. Napster: "The shot heard 'round the world" or "not with a bang but a whimper? Journal of Public Policy \& Marketing, Vol. 20,

Lerner, J., 1994, “The Importance of Patent Scope: An Empirical Analysis.” Rand Journal of Economics. Vol. 25, pp. 319-933.

Lerner, J., 2002, "Where Does State Street Lead? A First Look at Finance Patents.” Journal of Finance. Vol. 57. pp 901-930.

Lerner, J. and J. Tirole, 2002. "Some Simple Economics of Open Source.” Journal of Industrial Economics, Vol. 50, pp. 197-234

Levin, R., 1982. "The Semiconductor Industry.” In R. Nelson (ed.) Government and Technical Progress: A Cross-Industry Analysis. New York: Pergamon Press.

Levin, R.C., R. Klevorick, A. Nelson and S. Winter, 1987. "Appropriating the Returns from Industrial R\&D Brookings Papers on Economic Activity, pp. 783-820

Mansfield, E., 1986. "Patents and Innovation: An Empirical Study." Management Science 32.

Merges, R.P. and R. R. Nelson, 1990. "On the Complex Economics of Patent Scope." Columbia Law Review, Vol. 90. 
O’Donoghue, T., S. Scotchmer and J.F. Thiesse, 1998. "Patent Breadth, Patent Life, and the Pace of Technological Progress." Journal of Economics and Management Strategy Vol. 7, pp.1-32

Pakes, A., 1986. "Patents as Options: Some Estimates of the Value of Holding European Patent Stocks.” Econometrica Vol. 54, pp. 755-784

Pakes A. and M. Schankerman, 1984. "The Rate of Obsolescence of Knowledge, Research Gestation Lags and the Private Rate of Return to Research Resources." in Z. Griliches (Ed.), Patents, $R \& D$, and Productivity. Chicago: The University of Chicago Press.

Ritter, J., and H.C. Chen, 2000. “The Seven-Percent Solution.”Journal of Finance, Vol., 55, $1105-1131$

Rolfe J. and P. Troob, 2001. Monkey Business: Swinging Through The Wall Street Jungle. New York: Warner Books

Schankerman, M. and A. Pakes, 1986. "Estimates of the Value of Patent Rights in European Countries During the Post-1950 Period.” Economic Journal, Vol. 96., 1052-1077

Shapiro, C. and H. R. Varian, 1998. Information Rules: A Strategic Guide to Network Economy. Boston: Harvard Business School Press

Shirky, C. 2001, "Where Napster is Taking the Publishing World." Harvard Business Review, Reprint \#R0102M.

von Hippel, E., 1988. The Sources of Innovation. New York: Oxford University Press

Wilhelm, W.J. and J. D. Downing, 2001. Information Markets: What Businesses Can Learn from Financial Innovation. Boston: Harvard Business School Press 